\title{
CHANGES IN LAND-USE AND THE RIVER NETWORK OF THE GRABEN DYJSKO-SVRATECKÝ ÚVAL (CZECH REPUBLIC) IN THE LAST 242 YEARS
}

\author{
JAROMÍR DEMEK, MAREK HAVLÍČEK, ZDENĚK CHRUdinA, PETER MACKOVČIN
}

The Silva Tarouca Research Institute for Landscape and Ornamental Gardening (VÚKOZ), Public Research Institute, Prühonice, Department of Landscape Ecology Brno, Lidická 25/27, 60200 Brno, Czech Republic, E-mail: demekj@seznam.cz,marek.havlicek@vukoz.cz,zdenek.chrudina@vukoz.cz, peter.mackovcin@vukoz.cz.

Received: $25^{\text {th }}$ September 2008 , Accepted: $26^{\text {th }}$ December 2008

\begin{abstract}
Landscape-ecological parameters characterizing the landscape's structure, its function and changes over time (dynamics and development) play an important role as the indicators of sustainable development. Rapid changes in landscape patterns actually expressed by changes in land use are characteristic features of the contemporary cultural landscape. Both geography and landscape ecology have elaborated their own methodological approaches for monitoring of changes in landscape structure. The authors used historical topographical maps from the period 1764 to 2006 to monitor and study changes in land use and in the river network of the Graben Dyjsko-svratecký úval in the eastern part of the Czech Republic. Digital processing of maps in GIS milieu enabled high-quality quantitative assessment of changes that have occurred in cultural landscapes over 242 years. The quantitative study of land use changes by the Human society provides information on the intensity of landscape dynamics and development through the ages. The historical topographic maps are very useful as a source of information for such landscape-ecological studies.
\end{abstract}

Keywords: Graben Dyjsko-svratecký úval, landscape changes, land use, historical topographic maps

\section{INTRODUCTION}

The present interest in landscapes by both in the scientific community and the public, arises from rapid changes in the European cultural landscapes over recent centuries and from the union of geographical and biological sciences which has resulted in formation of the new scientific branch, known as the landscape ecology. From the author's perspective, the landscape is the land surface and its associated habitats viewed at the medium scales. In a landscape-ecological context, the landscape may be fruitfully viewed as a mosaic of heterogenic patches, networks (corridors) and nodes that together form a certain type of landscape structure. According to a Czech Republic technical standard (ČSN 837005 Landscapes), landscape structure represents the sum and relationship of those components forming the landscape, as well as the spatial distribution and relationship of lower taxonomic order complexes. Landscape ecology also includes geomorphology as applied to the design and architecture of landscapes (Allaby 2004). In a cultural landscape, the 
landscape structure is principally determined by the use of patches and corridors by humans. Among the key research topic in geography and landscape ecology today are those of monitoring changes in land use and land cover, as well as relating landscape pattern analysis with landscape forming processes. In this paper, the authors study changes in the interaction between temporal and spatial aspects of the land-use change and the river network in the Graben Dyjsko-svratecký úval in the Czech Republic over the last 242 years, including changes in the related flora and fauna and cultural components.

\section{Fig. 1: The Graben Dyjsko-svratecký úval in South Moravia (Czech Republic)}

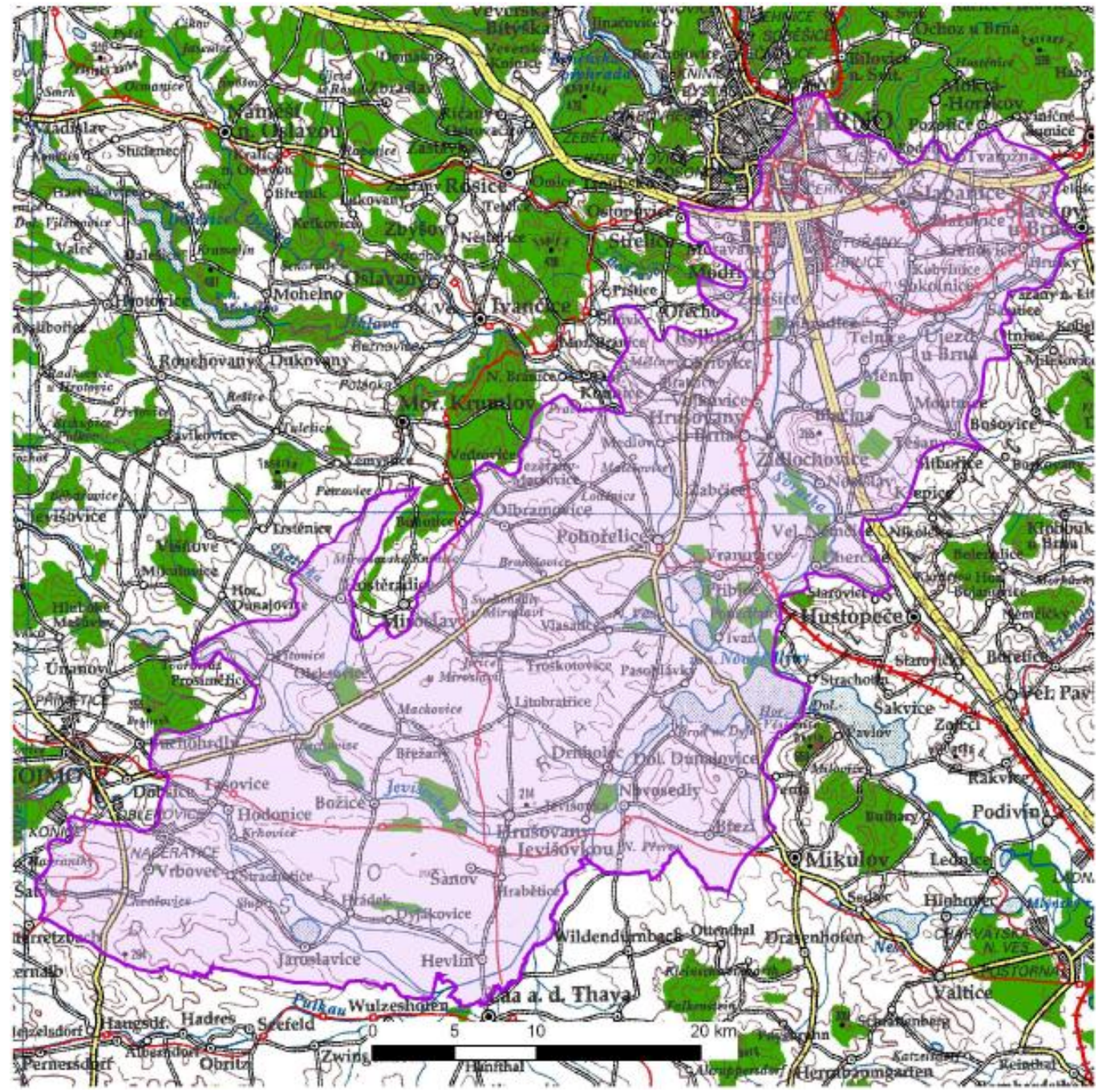




\section{METHODS}

\section{Study area}

The Dyjsko-svratecký úval Graben (Fig. 1) represents the westernmost link in the chain of the Outer-Carpathian Depressions chain. The Graben stretches south of the City of Brno between the geologically and geomorphologically old highlands of the Bohemian Massif (Brněnská vrchovina Highland and Českomoravská vrchovina Highland) in the west and the younger Central Moravian and South Moravian Carpathians in the east. The southern limit of the area forms the state boundary between the Czech Republic and Austria. The Graben occupies an area of $1454 \mathrm{sq}$. km. It has a flat or slightly undulation terrain made up of soft Tertiary and Quaternary deposits, typical of its creation through subsidence. The River Strata and its floodplain (Svitavsko-svratecká niva - Fig. 2) form the north-south axis of the Graben. The west-east axis is formed by the River Dye and its floodplain. The belts of floodplains and low river terraces along the main streams produce a landscape with a typically lowland character. The gently rising fringes of the Graben are composed of high river terraces, alluvial cones and hilly lands on Neogene deposits covered by Pleistocene loess. The Graben has a mean altitude $210 \mathrm{~m}$ a.s.l. The highest point in the Graben is Výhon Hill (355.5 m a.s.1.) near the town of Židlochovice. Climatically the Graben is amongst the warmest and driest climatic regions in the Czech Republic. Fertile chernozem and brown soil prevail in the lowlands and hills, while fluvisols have developed in the floodplains. From the botanical point of view, the area represents on of the most varied mosaic of ecosystems in the Czech Republic and is known as the Pannonian Thermophitic region (Mackovčin ed. 2007). Typical ecosystems include thermophilic oak woods and mixed oak-hornbeam, lime and oak stands. The floodplains display typical floodplain forests. The impact of humans on the natural ecosystems is the region has been very high.

The landscape Dyjsko-svratecký úval Graben represents one of the "old" settled areas of the Czech Republic. Mammoth hunting settlers lived in the area 25000 years B.P. The first milestone in the history of the cultural landscape, however, is represented by the Neolithic agricultural revolution, which started in about 5300 B.C. The Graben has marked the course of important trading routes, since prehistoric times, and especially those communicating between north and South Europe specializing in the exchange of salt, gold and amber for other goods (e.g. Amber Route). In the 5th Century A.D., Slavonic tribes settled in the Graben and the area went on to form the "core" of the Great Moravian Empire in the 8 th Century A.D. The Graben has long had a relatively dense population with several towns and many villages.

The older types of villages (i.e. 12th Century) were nearly always located close to a water source; hence, most of the settlements were located close riverbanks. Later settlements (i.e. 13th Century) were also built in the vicinity of rivers and brooks, but more frequently at confluences or on the upper reaches of brooks and rivers. Those settlements on the floodplains later had to move to higher areas (e.g. on low river terraces) to escape regular flooding during the Little Ice Age. Some villages were later deserted and never rebuilt.

According to V. Nekuda (1996) the causes of the desertion process were as follow

i) Structural changes in the local economy, i.e. introduction of a new land administration system (end of the 12th the beginning of the 13th centuries),

ii) The emergence of towns, e.g. Migration of population to the towns of Brno and Znojmo,

iii) Migration from the villages, i.e. villagers were forced to pay feudal rent from the 14 th Century and

iv) Wars that occurred between the 14th and 17th Centuries. 
Fig. 2: Geomorphological characteristics of the Dyjsko-svratecký úval Graben

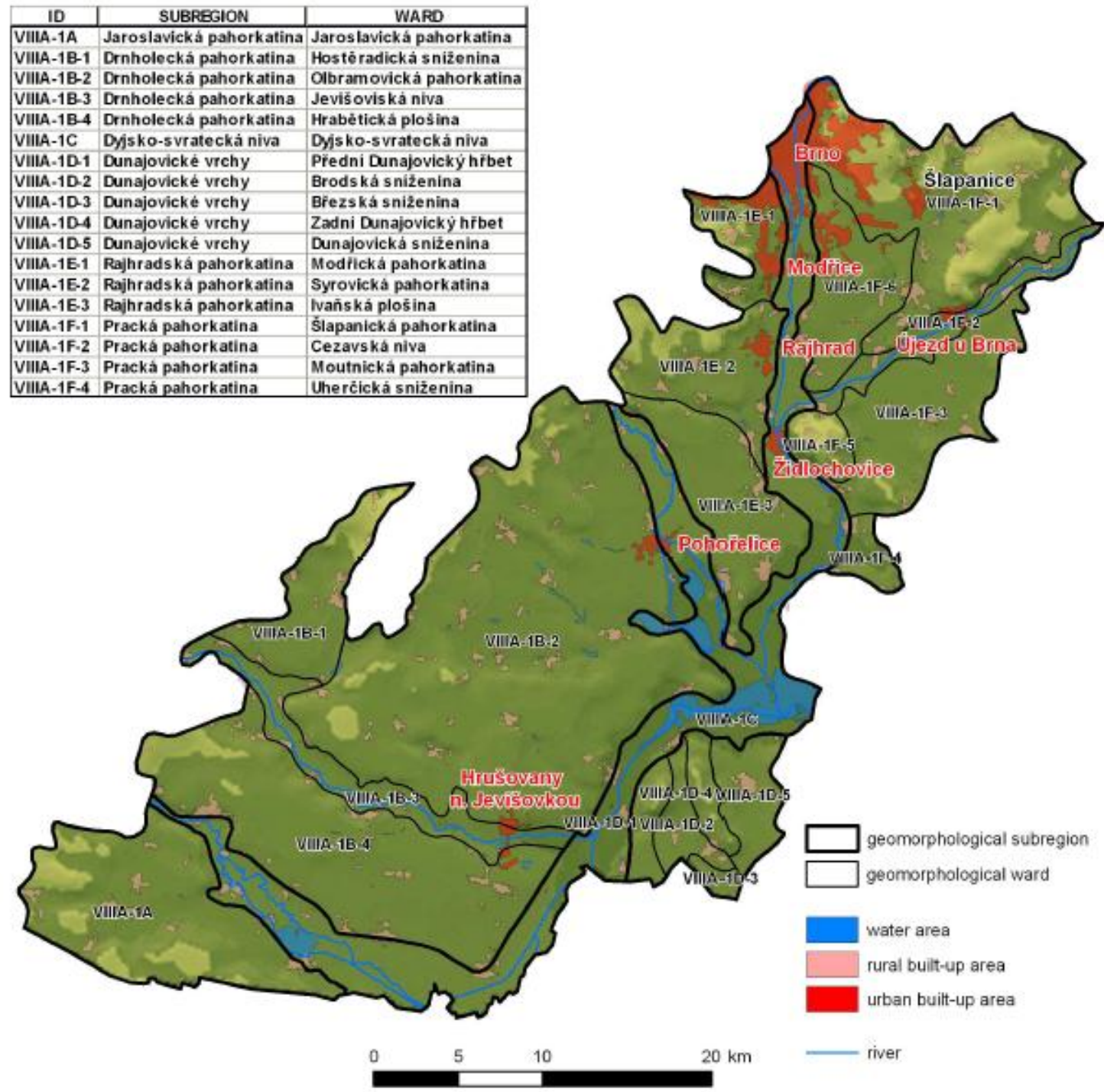

Many villages in the south-western part of the Graben became deserted during the battles between the Bohemian King Jiří z Poděbrad (George of Poděbrady) and the Hungarian King Mathias Corvinus in 1468 (e.g. at Čejkovice near Oleksovice, Popovice near Tasovice, Gnast near Dyjákovičky, Německé Borotice near Borotice). New villages, however, were founded during the 18th Century (e.g. Čejkovice 1711). The Thirty Years' War (1618-1648) also brought great devastation to the region. The pattern of agriculture in the Graben began to change around 1825. Fallowing (one third of the arable land was kept as fallow and used as pastures) was gradually changing to a system of crop rotation. The industrial revolution was also beginning to make itself felt in the region by the $1850 \mathrm{~s}$. 
The City of Brno annexed of the 23 neighbouring villages in 1919, which greatly increased the area of urbanized landscape. Changes occurred in the rural landscape due to the first Czechoslovak agricultural reform of 1920 which mainly affected feudal estates. After 1950, the collectivization and industrialization of Czechoslovak agriculture greatly affected the pattern of the rural landscape in the Graben Dyjsko-svratecký úval. As a result of collectivization, the varied mosaic of cultivated plots, still existing at the beginning of the 20th Century, were changed into large areas of monoculture.

At present, the landscape model is characterized by following the following features:

i) Humans are less present in the open landscape

ii) Direct Man's intervention in the landscape is less frequent but more powerful

iii) Environmental stress associated with traditional agricultural management is decreasing

iv) The role of disturbances related to industrial activities and urbanization increases (Pyšek, Sádlo, Mandák 2002).

Changes of land-use are used by many authors to evaluate cultural landscape changes (e.g. Lipský 1999, 2007, Pucherová et al. 2007, Boltižiar 2007), as they make it possible to evaluate the results of interactions between natural and socioeconomic driving forces in the landscape. The recent growth of landscape ecology owes much to the development of geographic information systems (GIS) technology, which is also used in author's research.

Unfortunately the most land-use mapping in the Czech Republic is spatially limited to more homogenous model areas and topological level (e.g. one or several cadastres). The Department of Landscape Ecology of the Silva Tarouca Research Institute for Landscape and Ornamental Gardening (VÚKOZ) in Průhonice is presently undertaking chorological mapping land-use for the whole Czech Republic over the period from 1836 to 2006 within the frame of research project MSM 6293359101 (part Quantitative analysis of the dynamics of the Czech landscape). This study is based on computer-supported analysis of the impact of human on the landscape using sets of large-scale historical topographic maps covering the whole of the country.

\section{METHODS AND MATERIALS}

Colour topographic maps of the $1_{\text {st }}$ (in Moravia 1764-1768) and 2nd (in Moravia 18361841) Austrian Military Survey at the scale 1:28 800 were acquired from the Austrian Military Archive in Vienna and scanned in the Laboratory of Geoinformatics at the J. E. Purkyně University, Branch in the town of Most. Colour originals of Military topographic maps of the 3rd Austrian Military Survey from 1876 at a scale 1: 25000 were procured for part of the Czech territory and black and white copies for the rest of the Republic from the Map Collection of Charles University of Prague and digitized by the authors at governmental Agency for Nature Protection and Landscape Conservation of the CR and at VÚKOZ Brno.

The authors were also able to digitize colour military topographic maps S52 (1955) and S42 (1990) on a scale $1: 25$ 000, which were kindly lent to the authors on the authority of the Ministry of Defense branch in the town of Dobruška were digitalized by the authors on a scale 1: 25 000. The 1: 10.000 raster graphic basic map of the Czech Republic was used for evaluation of land-use between the years 2002-2006. The maps of the 2nd and 3 rd Austrian Military Surveys were georeferenced at the Section of Geomatics of the University of West Bohemia in Plzeň with a positional accuracy $\mathrm{m}_{x y} 13-30 \mathrm{~m}$. The other maps were scanned and georeferenced by the authors at VÚKOZ and the positional accuracy was 10-15 m (Skokanová, Havlíček, Svoboda 2008). Nine land-use categories 
were distinguished when vectoring the maps, according to the methodology devised at VÚKOZ (Code 1. Arable land, Code 2. Permanent grassland, Code 3. Orchard and garden, Code 4. Vineyard, Code 5. Forest, Code 6. Water area, Code 7. Rural built-up area, Code 8. Urban built-up area, Code 9. Recreational area and Code 0. Others). As regards the final output maps of the project (which were printed in colour at a scale of 1: 200 000), only areas larger than 0.8 hectares $(0.5$ ha for water surfaces) were vectored. Calculations based on land-use change were undertaken by overlaying the vectored maps and calculating the amount of change in land-use- river length, sinuosity of rivers (the sinuosity index was calculated as the lengths of the river divided by the length of the valley) land use change as the percentage of total territory, change in the type of land-use, and dynamics of land use change over the whole surveyed period.. The scale of changes ranged from 0 (no change) up to 4 (maximum possible changes - Skokanová-Havlíček-Svoboda 2008). Based on these results, a map of "stable plots" was also constructed (see Fig. 10) for future use in restoration ecology. Restoration ecology.

The technical processing of vectorized maps in GIS milieu was carried out in the VÚKOZ Brno (Mgr. R. Borovec, Ing. R. Rysková, Ing. R. Eremiášová, Mgr. H. Skokanová PhD., Mgr. T. Stránská, Ing. J. Svoboda) with using ArcViewy 3.3, ArcGIS 9.1 SW software. The data are stored at VÚKOZ Brno, final colour maps are printed in the scale 1: 200000 .

The information obtained from the historical maps was further complemented through a literature search of historical and modern articles on the Graben Dyjsko-svratecký úval (e.g. Brázdil, R., Kirchner, K. et al 2007, Jurnečková, R., Kolejka, M. 1999, Nekuda, V. 1997, Peřinka, F.V 1904., Slavík, F.A. 1897, Vlček, VL. a kol. 1984)

\section{RESULTS AND DISCUSSION}

\section{Landscapes structures in the 18th Century}

Maps of the $1_{\text {st }}$ Austrian Military Survey of Moravia from 1764-1768 provide an unique picture of the landscape at the beginning of the agricultural revolution and prior to the industrial revolution. Several important changes in the development of the landscape occurred around this time. Firstly, the population of the Moravia began to increase at a faster rate than previously. Secondly the average gross domestic product per capita also appears to have increased somewhat more rapidly than previously. Thirdly, a number of important structural changes began to have an impact on the landscape at that time. It was a time of important technological and socioeconomic change and the start of the modern era in the development of landscapes in the Czech Republic.

Maps of the $1_{\text {st }}$ Austrian Military Survey are not based on a triangulation network and therefore georeferencing and computer supported elaboration is very difficult. A digital map of land use of that period therefore has not been available up until now. The original maps however, clearly indicate that the Graben Dyjsko-svratecký úval landscape during the 18th century was primarily rural, comprising agriculture, forestry and fishponds (see Fig. 3 and 4).

The 1st Austrian Military Survey map shows the Moravian capital town of Brno as a sizeable baroque fortified town surrounded by a town wall with bastions in the northern part of the Graben (Fig. 4). 
Fig. 3: A detail from a map sheet of the 1st Austrian Military Survey showing the surroundings of the town of Hrušovany nad Jevišovkou. Many fishponds are apparent in the river valleys.

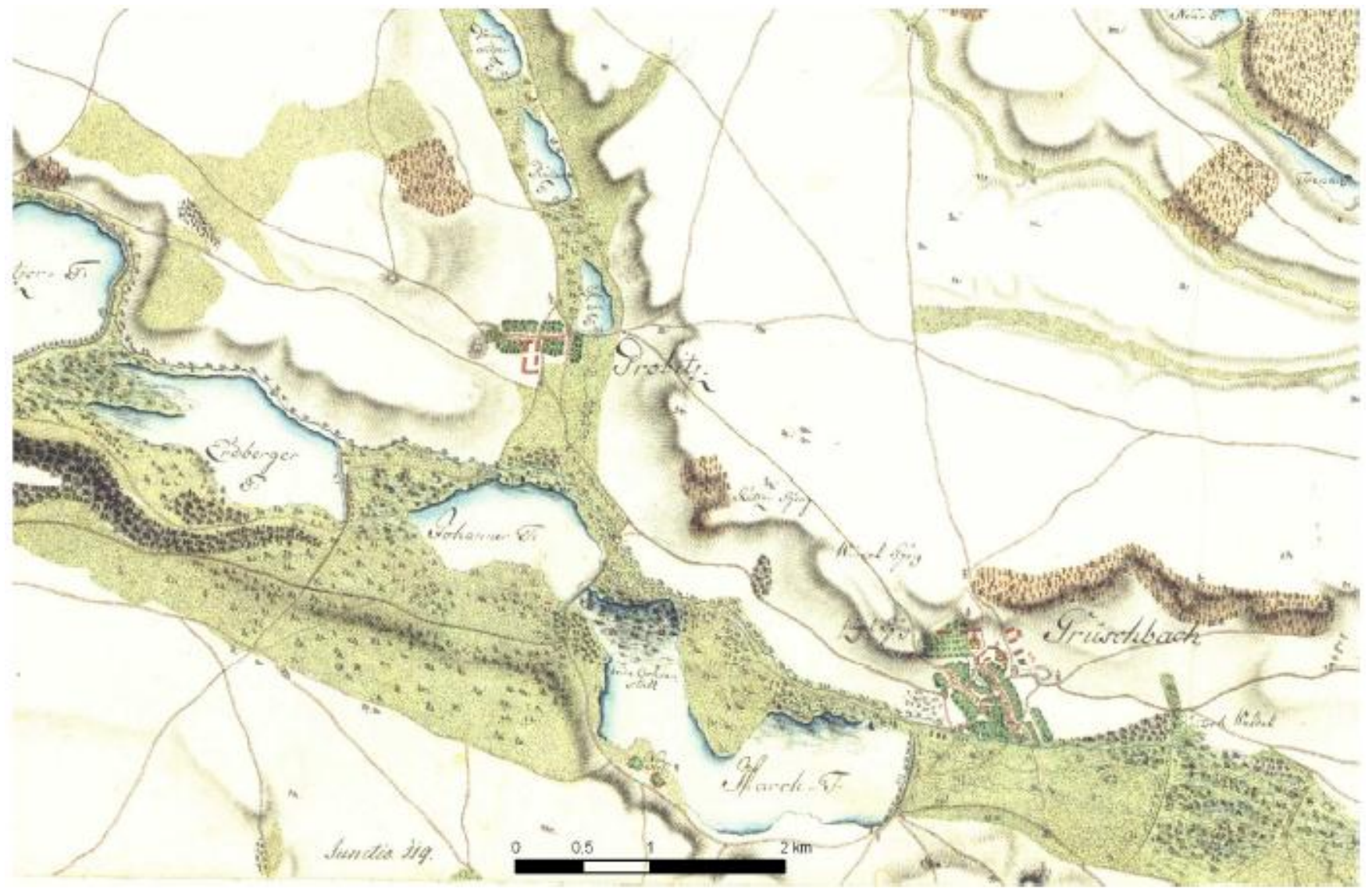


Due to the lack of triangulation net, the evaluation of the hydrostructures is far from precise on these early maps (see Fig.3). The lowest parts of the Graben comprise floodplains composed of fluvial sediments from the water courses. The thickness of the floodplain deposits is about $7 \mathrm{~m}$. In the 18 th Century, the floodplains were comprised almost entirely of areas of floodplain forests, meadow and fishponds. In some areas, however, the forests had already been felled, and meadows ploughed up and transformed into fields. Rivers were still freely meandering and anastomosing on the floodplains.

According to the maps of the $1_{\text {st }}$ Austrian Military Survey, the length of the Svratka R., at this time was approximately $53.7 \mathrm{~km}$. The Svratka River was anastomosing near settlements Modrice and Rajhrad to the south of the town of Brno. Anabranching channels of the Svratka River, where the flow divided into two and more separate channels developed in the floodplain near the villages of Velké Němčice, Uherčice and Vranovice. The map (Fig. 4) shows a number of separate channels (anabranches) incised into the floodplain, dividing it up into a number of islands. The resultant islands had elevation similar to that of the surrounding floodplain. Individual anabranches were straight or meandering. The islands were stable features and covered with floodplain forests. The banks of low-energy anabranches were stabilized by the riparian vegetation. In the floodplain Svitavsko-svratecká niva, the map shows fishponds, meadows and relatively extensive floodplain forests. The Černovice wetland forest (Černovický les) is shown in the northern part of the floodplain, further to the south, than the floodplain forest at the villages of Rebešovice and Rajhrad. The above mentioned river islands were also forested (forest Nosislavský les, Vranovický les forest).

The River Svitava, a tributary of the River Svratka, emptied into the main river via two arms - the first near the village Komárov and the second one (main) arm near the village Dolní Heršpice. On the map, traces of a third arm can be found among the villages of Černovice, Holásky and Rebešovice.

Other tributaries, namely River Cézava (Litava R.). And the Šatava R. were prevented from joining the course of the main River Svratka directly by natural levees, which flanked bed of the river. Tributaries Cézava and Šatava R .Therefore had to run parallel to River Svratka for some distance (so called contact Yazoo).

The Cézava R. bed had already been trained between villages Slavkov u Brna and Vážany by this time. A large fishpond was situated in the floodplain Cézavská niva near the village of Žatčany Two fishponds were situated downstream near Měnín - the larger of these, the fishpond Měnínský rybník, was originally called Nesyt and founded 1396 (Kratochvíl 1913), while the smaller fishpond was called Žerotín (Kratochvíl 1913 - on the map nameless).

Typical of the lower reaches of the River Jihlava floodplain (Dolnojihlavská niva Floodplain) were meadows and a large fishpond system near the town of Pohořelice. The large fishponds had already been built by the 16th Century, and include the Starý rybník fishpond (built 1520, 130 hectares), the Novoveský rybník fishpond (1536, 174 hectares) and the Vrkoč fishpond (built 1552, 168 hectares). Water for the fishponds was supplied from the Jihlava River through the millrace Mlýnský náhon (weir Cvrčovice). Larger floodplain forests were to be found near the village Ivan̆ just before the confluence of the rivers Jihlava and Svratka.

In the 18th Century, the River Dyje meandered and anastomozed of the floodplain downstream from the town of Znojmo. The length of this section of the Dyje R., according maps of the $1_{\mathrm{st}}$ Austrian Military Survey, was approximately $53.7 \mathrm{~km}$. The river shows the 
largest sinuosity of all riverbeds in the Dyjsko-svratecký Graben (index 2.07 - see Tab. 3). This part of the Dyje R. floodplain (Středodyjská niva), consist of a mosaic of meadows and fields. A large fishpond was built in the floodplain near the village Jaroslavice. Known as the Zámecký rybník fishpond (190 hectares) it was historically bound to the chateau of Jaroslavice. Unlike in the Svitava-Svratka floodplain, anabranching channels, where the flow is divided into two or more separated channels, are relative rare in the Dyje R. floodplain. Multichanneled sections of the Dyje R. are shown on maps of the $1_{\text {st }}$ Austrian Military Survey, however, in the surroundings of villages Mušov and Dolní Věstonice.

The length of the Jevišovka R. (left tributary of the Dyje R.) was approximately $36 \mathrm{~km}$ at this time in the area under study. In the 18th Century, a system of 8 fishponds was maintained on the floodplain of the lower reaches of Jevišovka R (Fig. 3). Upstream of the town of Hrušovany nad Jevišovkou, there was large fishpond named March, a fishpond named Johanner to the south of the village of Pravice.

And the Erdberger and Božický rybník fishponds further upstream. A fishpond named Krrídlovický rybník was situated near the village of České Křídlovice and the fishpond Borotický rybník was situated at the village of Borotice. Two fishponds were situated between the villages of Tvořihráz and Prosiměrice. In the asymmetric valley of the creek Březanka (a left tributary of the Jevišovka R.) four fishponds were situated between villages of Břežany in the north and Pravice in the south (the Weith, Domowitzer, Mutter and Pzauer fishponds). Fishpond systems were also found in other valleys of the Drnholecká pahorkatina Hilly land (e.g. on other left tributaries of the rivers Jevišovka. Skalička and Křepička).

In the Neogene hilly lands in the western part of the Graben (the Hilly lands Jaroslavická pahorkatina and Drnholecká pahorkatina) the landscape is typically rural, mainly comprising arable land, vineyards and villages. Many fishponds systems are concentrated not only in the floodplains of the main rivers, but also in valleys of the smaller tributaries (e.g. valley of Břežanka Creek has a system of 4 fishponds, valley of Litobratčický potok Creek has a system of 6 fishponds).

The slopes of two structural Neogene ridges in the Hills Dunajovické vrchy in the southern part of the Graben were covered by vineyards on agricultural terraces, while bottom of the combe among them was covered by fields. The flat surfaces of the Quaternary river terraces in the Hilly land Rajhradská pahorkatina in the northern part of the Graben (Fig. 2) were also used as arable land. Vineyards are situated close to the villages of Zelešice, Bratčice, Sobotovice and Ivaň. The landscape structure around the Pratecký kopec Hill in the northeastern part of the Graben is more differentiated due to a more dissected relief of the Hilly land Pracká pahorkatina (Fig. 2). Typical features in the valleys of the Svratka R. tributaries are large fishponds and systems of smaller fishponds. For example, large fishponds occur in the vicinity of the village of Měnín and a system of 10 smaller fishponds in the valley of the Creek Dunávka. Fishponds were also located in the villages of Kobylince (in the Zlatý potok Brook valley) and Milešovice (in the Mlýnská dolina valley). Výhon (354.5 m a.s.1.) in the Hilly land Pracká pahorkatina is the highest point of the Graben Dyjsko-svratecký úval and its steep slopes which are prone to many landslides were covered by vineyards. The flat cryopediments at its foot were used as arable land.

Villages and towns were connected by a network of earth roads maintained by the local authorities. The technical conditions for this pattern of roads were very poor. Some rural roads were simply narrow hollow ways. These hollow ways concentrated rainwater and gradually changed into gullies. In 1778, the Austrian empress Maria Theresa published a 
decree concerning the construction of a system of imperial paved roads. Imperial roads arising from the Brno town gates and leading to Vienna in the south (1727-1754 Kratochvíl, 1910, p. 33), the towns of Olomouc in the north-east and Jihlava in the west had already been constructed during 1727 to 1754 , by 1740 and by 1752 respectively.

The railway network began to develop from 1839, when the railway from Vienna to Brno was completed. Other railways lines constructed in the Graben include the following: Brno - Střelice (1853), Brno - Přerov (1869), Vranovice - Pohořelice (1895), Hrušovany u Brna - Židlochovice and Střelice - Hrušovany nad Jevišovkou - Hevlín (1895), Hrušovany nad Jevišovkou - Znojmo (1870), Hrušovany nad Jevišovkou - Mikulov (1872) and Břeclav Mikulov (1873).

\section{Landscapes structures in the first half of the 19th Century}

The picture of landscape structures in the Graben Dyjsko-svratecký úval in the first half of the $19_{\text {th }}$ Century is based on maps of the 2 nd Austrian Military Survey undertaken during 1836 - 1841 on a scale 1:28 800 (Fig. 4).

Arable land predominates in the Graben representing (74.08\%) of the land cover (Table1). The rural landscape of the Graben comprised both natural (floodplains, lowland plains on loess, hilly lands on Quaternary and Neogene deposits) and agricultural features, as well as such cultural features as local architecture, churches, castles and other historical monuments At $14.5 \%$ the share of permanent grassland was still high (14.43\%), especially on the floodplains. The share of forests $(4.85 \%)$ and water surfaces $(0.21 \%)$ was also relatively high. Of these, the forest was floodplain forests and the water surface area was mainly represented by fishponds.

The historical core of Brno was still surrounded with the fortifications in this set of maps, thought it is obvious that demolition works had already begun on most of the town gates, on the medieval inner fortification wall (taken down completely between 1858 - 1863) and there was backfilling of the most town moats. These were replaced, for example, by constructions such as the main train station of the Vienna to Brno line, which was completed in 1839. Brno experienced a boom in industry and trade in this period. Typical of the development of this type of Czech urbanized landscape was the building of industrial works directly in the town or in suburban villages close to housing areas. The surface area of the Brno suburbs was increasing. Settlements immediately adjacent to the town were changing from independent villages directly into industrial suburbs. 
Journal of Landscape Ecology (2008), Vol: 1 / No. 2.

Table 1: Changes in land use in the Graben Dyjsko-svratecký úval in the period $1836-2006$

\begin{tabular}{|c|c|c|c|c|c|c|c|c|c|c|}
\hline \multirow{2}{*}{ Type of land use } & \multicolumn{2}{|c|}{ 1836-1841 } & \multicolumn{2}{|c|}{$1875-1876$} & \multicolumn{2}{|c|}{ 1953-1955 } & \multicolumn{2}{|c|}{ 1991-1992 } & \multicolumn{2}{|c|}{$2002-2006$} \\
\hline & hectares & $\%$ & hectares & $\%$ & hectares & $\%$ & hectares & $\%$ & hectares & $\%$ \\
\hline Arable land & 107764 & 74,0 & 118662 & 81.6 & 119359 & 82.2 & 112161 & 77.1 & 110353 & 76.0 \\
\hline $\begin{array}{l}\text { Permanent } \\
\text { grassland }\end{array}$ & 20994 & 14.5 & 11294 & 7.8 & 4096 & 2.8 & 1449 & 1.0 & 2256 & 1.5 \\
\hline Orchard & 669 & 0.5 & 870 & 0.6 & 2330 & 1.6 & 2931 & 2.0 & 2550 & 1.7 \\
\hline Vineyard & 5456 & 3.7 & 4595 & 3.2 & 2617 & 1.8 & 4014 & 2.8 & 3709 & 2.5 \\
\hline Forest & 7059 & 4.8 & 6330 & 4.3 & 8949 & 6.1 & 9215 & 6.3 & 10438 & 7.2 \\
\hline Water area & 310 & 0.2 & 37 & 0.03 & 841 & 0.6 & 2846 & 2.0 & 2748 & 1.9 \\
\hline $\begin{array}{l}\text { Rural built-up } \\
\text { area }\end{array}$ & 3014 & 2.1 & 3275 & 2.2 & 5331 & 3.7 & 7850 & 5.4 & 7300 & 5.0 \\
\hline $\begin{array}{l}\text { Urban built-up } \\
\text { area }\end{array}$ & 194 & 0.1 & 386 & 0.3 & 1723 & 1.2 & 4067 & 2.8 & 5065 & 3.5 \\
\hline $\begin{array}{l}\text { Recreational } \\
\text { area }\end{array}$ & 0 & 0.0 & 0 & 0.0 & 86 & 0.1 & 571 & 0.4 & 565 & 0.4 \\
\hline Other & 3 & 0.1 & 15 & 0.01 & 129 & 0.1 & 358 & 0.2 & 478 & 0.3 \\
\hline Total & 145466 & 100.00 & 145466 & 100.00 & 145466 & 100.00 & 145466 & 100.00 & 145466 & 100.00 \\
\hline
\end{tabular}


Fig. 4: Land use in the Dyjsko-svratecký úval Graben around 1836 -1841

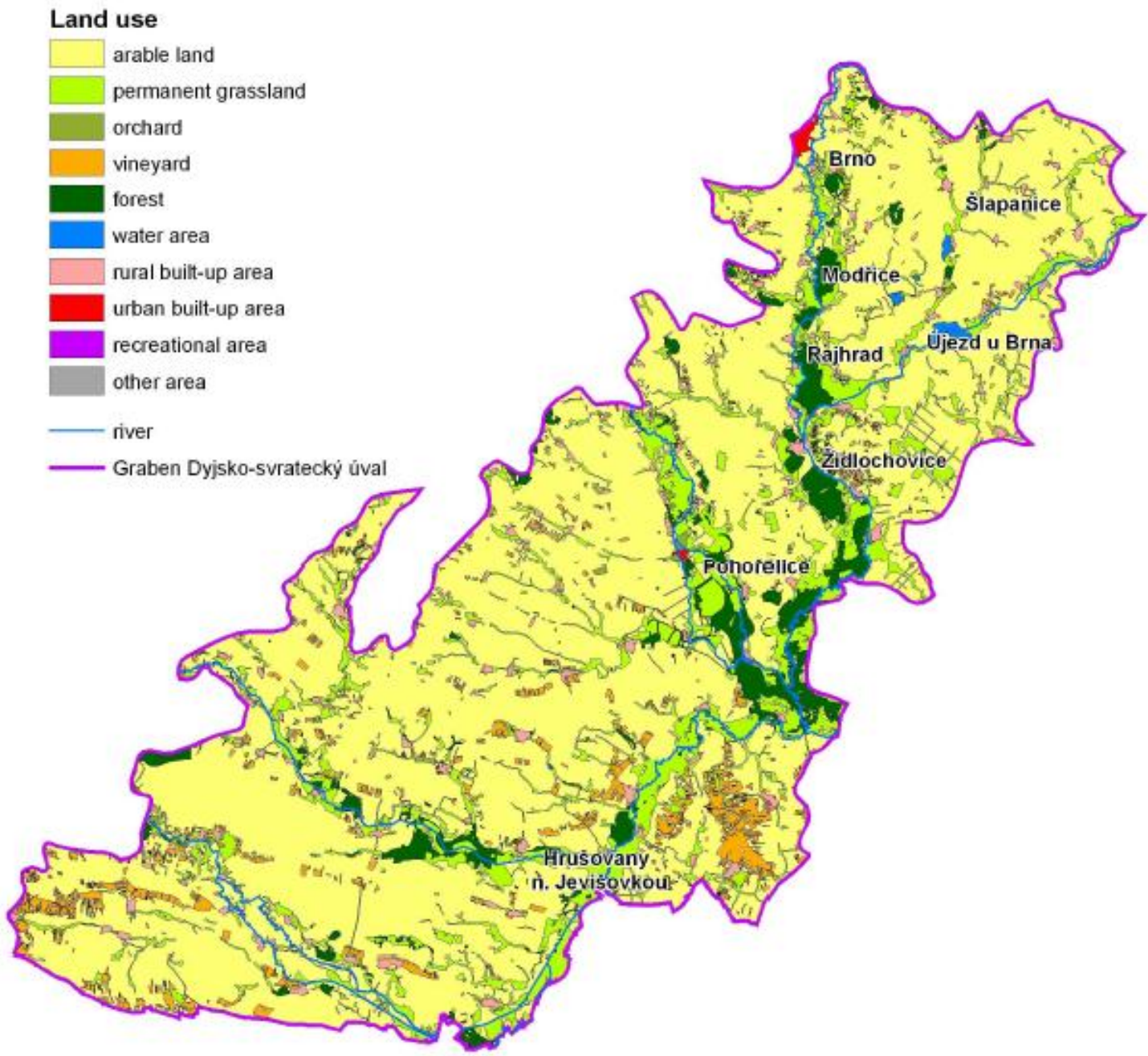


Maps of the 2nd Austrian Military Survey still show the rivers to be forming free meanders and anastomosing in some sections (Fig. 4) The degree of connectivity (i.e. the transfer of matter and energy from one landscape zone or location to another) is still high. The authors were able to distinguish both longitudinal and lateral connectivity within the Graben. Human activities in the landscapes caused a gradual reduction in connectivity though the construction of weirs, races and embankments. Connectivity was also reduced by relatively small structures, such as balks and agrarian terraces, which tended to fragment the landscape. The floodplains still functioned as ecotons among water courses and adjoining slopes in this period, which secured transport of matter, energy and information in both longitudinal and cross direction.

The length of the Svratka R. riverbed in the Graben was $52.50 \mathrm{~km}$ in this time (see Tab. 2 ) and the degree of sinuosity (sinuosity index) was 1.76 (see Table 3 ). The sinuosity index was calculated as the length of the river divided by the length of the valley.

The length of the Jihlava R. in the Graben was $26.32 \mathrm{~km}$ and the sinuosity index was 1.75. The Svitava R. opened into the Svratka R. below the village of Dolní Heršpice (a river network node). The greatest changes, however, are seen in the number of fishponds. Many fishponds were emptied and their beds changed into arable land. For example: the fishpond Modřický rybník and fishponds in the village of Velké Němčice (the Mojžíš, Zádvorník, and Brodač fishponds) in the floodplain Svitavsko-svratecká niva were all emptied at this time.

Table 2: Changes in the length $(\mathrm{km})$ of the main rivers in the Dyjsko-svratecký úval Graben over time

\begin{tabular}{|l|l|l|l|l|l|l|}
\hline RIVER & $\mathbf{1 8 3 6}$ & $\mathbf{1 8 7 6}$ & $\mathbf{1 9 4 4}$ & $\mathbf{1 9 5 4}$ & $\mathbf{1 9 9 1}$ & $\mathbf{2 0 0 7}$ \\
\hline SVRATKA & 52.50 & 44.62 & $\mathbf{4 0 . 2 5}$ & 40.21 & 35.33 & 36.75 \\
\hline CÉZAVA & 28.24 & 26.48 & ---- & 24.46 & 24.41 & 24.48 \\
\hline JIHLAVA & 26.32 & 25.20 & 25.36 & 25.55 & 24.52 & 24.97 \\
\hline DYJE & 68.39 & 67.14 & ------ & 61.46 & 59.11 & 60.15 \\
\hline JEVIŠOVKA & 31.82 & 32.36 & ------ & 31.79 & 31.46 & 31.49 \\
\hline
\end{tabular}

"-..-.-"indicates no data available

Table 3: Changes in the index of sinuosity of the main rivers in the Dyjsko-svratecký úval Graben over time

\begin{tabular}{|l|l|l|l|l|l|l|}
\hline RIVER & $\mathbf{1 8 3 6}$ & $\mathbf{1 8 7 6}$ & $\mathbf{1 9 4 4}$ & $\mathbf{1 9 5 4}$ & $\mathbf{1 9 9 1}$ & $\mathbf{2 0 0 7}$ \\
\hline SVRATKA & 1.76 & 1.50 & 1.35 & 1.35 & 1.22 & 1.23 \\
\hline CÉZAVA & 1.24 & 1.17 & ---- & 1.09 & 1.08 & 1.09 \\
\hline JIHLAVA & 1.47 & 1.40 & 1.41 & 1.42 & 1.36 & 1.39 \\
\hline DYJE & 1.77 & 1.73 & ---- & 1.58 & 1.54 & 1.54 \\
\hline JEVIŠOVKA & 1.22 & 1.22 & ---- & 1.20 & 1.19 & 1.19 \\
\hline
\end{tabular}

"indicates no data available

A map from 1838 indicates, however, that some large fishponds, such as the fishpond Žatčanský rybník on the Cézava R. and the fishpond Sokolnický rybník on the creek Sokolnický potok (Dunávka) were preserved. The large fishpond Měnínský rybník and the smaller fishpond Žerotín near the village of Měnín were drained in 1824 and changed into fields (Kratochvíl 1913). Wetlands between the villages Zbýšov and Žatčany were also drained. Large fishponds in the floodplain Dolnojihlavská niva, such as the fishpond Nový rybník, Starý rybník, Vrkoč and Nový rybník downstream from the town of Pohořelice and 
fishpond Novoveský rybník on the creek Olbramovický potok were all emptied.

Map of the floodplain Středodyjská niva show the first trained river sections (e.g. between the villages of Jaroslavice and Nový Přerov). The training is apparent along the present-day state border between the Czech Republic and Austria. Abandoned meander arms that were cut off by the training became oxbow lakes. The fishpond Zámecký rybník near the village of Jaroslavice in the floodplain Středodyjská niva was emptied at this time and the land was used as an arable land for a long time. The millrace Dyjsko-mlýnský náhon was constructed parallel to the Dyje R.

There were no more fishponds in the floodplain of the Jevišovka R. The emptying of fishponds caused anabranching of the riverbed at the sites of former fishponds. The river course between the villages of Božice and Hrušovany nad Jevišovkou was moved to the sites of the former fishponds and straightened. Some abandoned stretches of the former Jevišovka riverbed were preserved as oxbows.

\section{Landscape structures in the second half of the 19th Century}

Many changes took place in the Dyjsko-svratecký úval Graben over the period between the 2nd (1836-1841) and 3rd (1876-1877) Austrian Military Survey (Fig. 5, Table 1). Land use changed on $18.08 \%$ of the territory (Table 7). This change in land-use disturbed the hitherto dynamic equilibrium between geomorphical and ecological processes. The rate of landscape changes had accelerated by the 1840s. The share of arable land had increased to $81.57 \%$ of the territory over this period. In contrast, the share of permanent grassland had decreased to $7.76 \%$ and whiles the share of forests, and especially floodplain forests had also decreased slightly to $1.52 \%$. Farmers changed $7.42 \%$ meadowland into fields during this period of agricultural intensification. The water surface area decreased dramatically due to drainage of fishponds, now representing just $0.03 \%$ of the land's surface. This represents the lowest number amount of water surface over the whole period from 1836 to 2006. The share of built-up land slightly increased slightly 2.21 to $2.45 \%$, especially in the City of Brno and its environs.

Table 7: Dynamics of land-use changes over individual periods in the Dyjskosvratecký úval Graben

\begin{tabular}{|l|l|l|}
\hline PERIOD & $\begin{array}{l}\text { LENGTH OF THE PERIOD IN } \\
\text { YEARS }\end{array}$ & \% OF CHANGED PLOTS \\
\hline $1841-1876$ & 35 & 18.08 \\
\hline $1876-1955$ & 79 & 18.30 \\
\hline $1955-1992$ & 37 & 16.67 \\
\hline $1992-2006$ & 14 & 7.98 \\
\hline
\end{tabular}

Maps of the 3rd Austrian Military Survey of 1875-1876 show a rapid sprawl of the City of Brno following the demolition of its fortifications. The removal of the fortification belt facilitated the sprawl of the urban landscape into the Svitavsko-svratecká niva Floodplain and into the Hilly land Šlapanická pahorkatina. In the floodplain, an industrial zone formed around the Svitava riverbed (streets Cejl, Křenová and Dornych streets). Machine and textile works were built right beside dwelling houses. Backfills and embankments protected the structures on the low land against inundation during floods. 


\section{Fig. 5: Land use in the Dyjsko-svratecký Graben around 1875 - 1876}

\section{Land use}

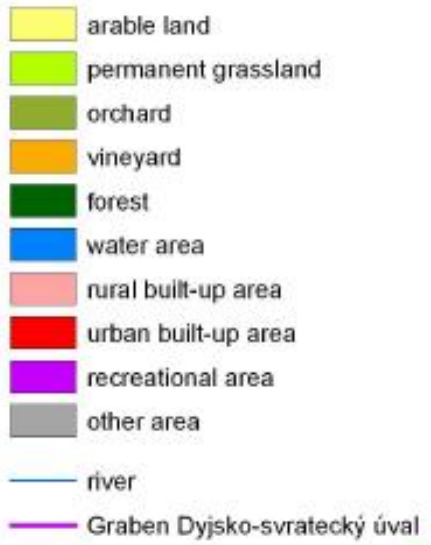
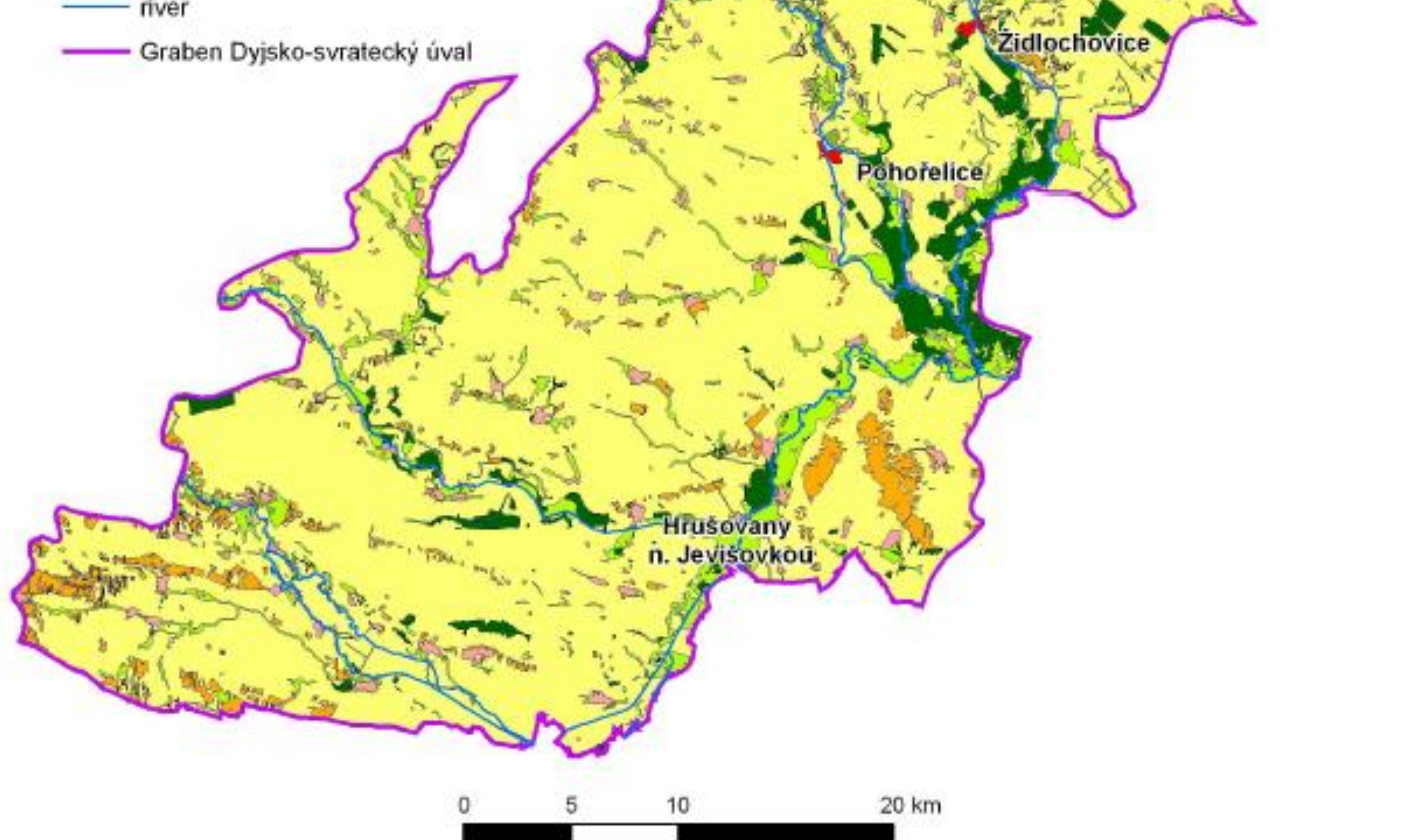

The training of the rivers Svratka and Svitava was launched in 1848. The aforementioned hydrologic node - the confluence of the rivers Svratka and Svitava, was moved from the village of Horní Heršpice southwards to the village of Přizřenice and a new river network node was constructed. A new deeper river channel was excavated from the City of Brno in the north to the village of Vojkovice in the south, which was then embanked (Kratochvíl 1910). Channelized stretches and embankments, built to contain floodwaters resulted in broken connectivity. River training caused fragmentation of the floodplains, changed the lengths of river courses and changed also the index of sinuosity. The old main riverbed of the Svratka R. at Rajhrad was used as a millrace Vojkovický (Mlýnský) náhon.

Maps of the 3rd Austrian Military Survey show that the length of the Svratka riverbed had been shortened to $44.62 \mathrm{~km}$ and that of the River Jihlava to $25.20 \mathrm{~km}$ due to the training (Table 2). The sinuosity index changed too (see Table 3). The riverbeds of tributaries such 
as the River Ŕíčka were also channelized and longitudinal connectivity was greatly disrupted by weirs. In many cases, migratory pathways for fish were blocked. In addition, more fishponds such as the Pouzdřanský rybník fishpond were emptied.

In the second half of the 19th Century the fishpond Zatčanský rybník was drained and a network of open drains was constructed on its bed. On the other hand, some open drains on the bed of the former large fishpond Měnínský rybník were backfilled.

The floodplain of the Jihlava R. was regularly flooded (Kratochvíl 1913) and some floods are also reported for the floodplain of the Svratka R. (Brázdil, Kirchner et al. 2007). The lower parts of the floodplains were protected by low dykes (so called farmer's dykes). The floodplain Jevišovská niva was also subject to flooding with floods occurring in, for example, 1862 and 1882 (Peřinka 1905). The riverbed of the Dyje R. was trained between the years $1887-1890$.

In 1850, the City of Brno had annexed 32 villages in its hinterland (Demek et al. 2007), which resulted in an enlargement of the urban landscape. In the same year, the construction and extension of the imperial road system was completed (Musil 1987). At almost the same time, i.e. in the period 1840 to 1875 , the major railroad lines were developed and took over the long-distance transport. In addition to the main railroad between Vienna - Brno previously mentioned, railroads were also constructed from Brno to Zastávka (1853) and from Brno to Přerov (1869). This resulted in a dramatic expansion of the secondary (district) road network, the density of which can be compared with the density of rivers in the landscape. The railways, the imperial and district roads and the network of connected ditches all resulted in fragmentation of the landscape. On the other hand, roads were lined with fruit trees. Many villages were connected by unpaved trails even as late as 1897 (Slavík 1897).

There were many small loam pits with brickyards in operation during this period. Mining landscapes were formed by large sand and gravel pits were concentrated on the Turany river terrace south-east of Brno and in Hodonice river terrace to the west of Znojmo.

During the long period of time between 1875 and 1955 land use changed on $18.39 \%$ of the territory, documenting the gradual decrease in the intensity of change in the rural landscape and the stabilization of the area of arable land. The intensity of meadows conversion to arable land was also decreasing, with only $4.39 \%$ of the meadows changing use in this period. On the other hand, the $2.12 \%$ of arable land was reforested. The share of forests increased to $6.15 \%$ of total territory due to reforestation of less productive land. An interesting feature of this period is the urbanization of villages and the grow of Brno. The decrease in the number of orchard and vineyards and their change into arable land continued throughout this period (Fig. 6).

The most conspicuous change in the rural landscape of the Graben during this period was introduction of Austrian agrarian reform (known as raabization) and drainage of a large number of fishponds in this period. Their beds were used to grow sugar beet or were turned in orchards or meadows (Jeleček 1985, 1991).

\section{Landscape structures in the first half of the 20th Century}

The $1_{\text {st }}$ Czechoslovak land reform following World War I distributed most of the land to peasants and accentuated the mosaic of small fields in the rural landscapes. This type of rural landscapes still prevailed in the Graben Dyjsko-svratecký úval in the first half of the 20th Century. The Czechoslovak topographic maps from the period 1918 - 1945 show that the floodplain forests in the floodplain Svitavsko-svratecká niva were nearly all felled at 
this time. (This set of maps has not yet been vectorized, as they do not cover the whole territory of the Czech Republic). We does know, however, that arable land prevailed also in the floodplain. The length of the Svratka riverbed had been shortened to $40.25 \mathrm{~km}$ (Table 2) and the sinuosity index had decreased to 1.35 (Table 3). Between August and September 1938, a major flood occurred in the Svratka and Svitava catchment. In City of Brno the flood wave culminated at 360 m3. s-1 (Němec, Hladný, eds 2006) and the floodplain Svitavsko-svratecká niva downstream was flooded. The construction of the Brno-Kníničky dam on the Svratka R. in 1941 (upstream of the City of Brno) reduced the number floods in the Svratka R. floodplain. Reduction of flooding broke the relationship between the watercourses and the floodplain's surface, however, and thus the accumulation of fluvial sediments on the floodplain surface, erosion by floodwaters and transport of sediments downstream were limited. Lateral connectivity was reduced by a dramatic reduction in the frequency, extent and duration of overbank events. Vertical transfers were also reduced, as recharge of the underlying alluvial aquifer took place only when floodwater inundated the floodplains.

In addition the share of forests had increased to $6.15 \%$ due to reforestation of less productive land. Also the share of water surfaces had increased to $0.58 \%$ due to revitalization of fishponds after World War II (see below).

The growth in the use of the car transportation from the beginning of the $20_{\text {th }}$ Century made it necessary to control the amount of dust produced on roads and air pollution, for which tarring of the roads's surface was found to be the most efficient.

\section{Landscape structures in the second half of the 20th Century}

A new colour set of Czechoslovak military topographic maps (S52) was published during 1952-1955. These maps not only show the effects of "post-War II stagnation" in rural settlements but also the growth of Brno's urbanized landscape onto cost fields, gardens and orchards (Fig. 6). The map set S52 illustrates recreational landscapes of summerhouses and garden colonies on the margins of urban landscapes for the first time. The total share of this type of landscapes in the Graben, however, was still small at $0.06 \%$ (Table 1).

Further communes (villages) were annexed by Brno in 1960. Urbanized area in the Graben Dyjsko-svratecký úval now included the village of Holásky and a part of the village of Moravany, now called Nové Moravany (Dřímal, Peša et al. 1973). In 1971 the city was enlarged with the inclusion of another eight municipalities. After 1989, a number of urban developmental zones were created in Brno, such as the Southern Centre brownfield site in the Svitava R. floodplain and the Černovická terasa Terrace on the Tuřany river terrace (Fig. 6).

The S52 maps also document the re-establishment of large fishponds near of the town of Pohořelice, including fishponds Starý rybník, Nový rybník, Novoveský rybník and fishpond Vrkoč (168 hectares - Fig. 6). The revitalization project was begun in 1948 and finished by 1953. The fishpond Čahoun was built in 1972. The S42 maps also show, that restoration of the large fishponds Jaroslavické rybníky near the village Jaroslavice in the floodplain Středodyjská niva has been completed (the fishpond Zámecký rybník 190 hectares and fishpond Horní rybník 59 hectares has been re-established in 1948). The share of water surfaces in the landscape of the Graben had increased by $0.58 \%$ by 1955 (Table $1)$.

The Krhovice - Hevlín irrigation canal was constructed $\mathrm{n}$ the second half of the $20_{\text {th }}$ Century, using the water from the Dyje R. At the same place, the aforementioned Dyjsko- 
mlýnský náhon Millrace divided the main course of the Dyje R. The riverbed was trained over the river section between the village of Nový Přerov and the confluence of Dyje and Svratka Rivers.

Fig. 6: Land-use in the Dyjsko-svratecký úval Graben around 1953 - 1955
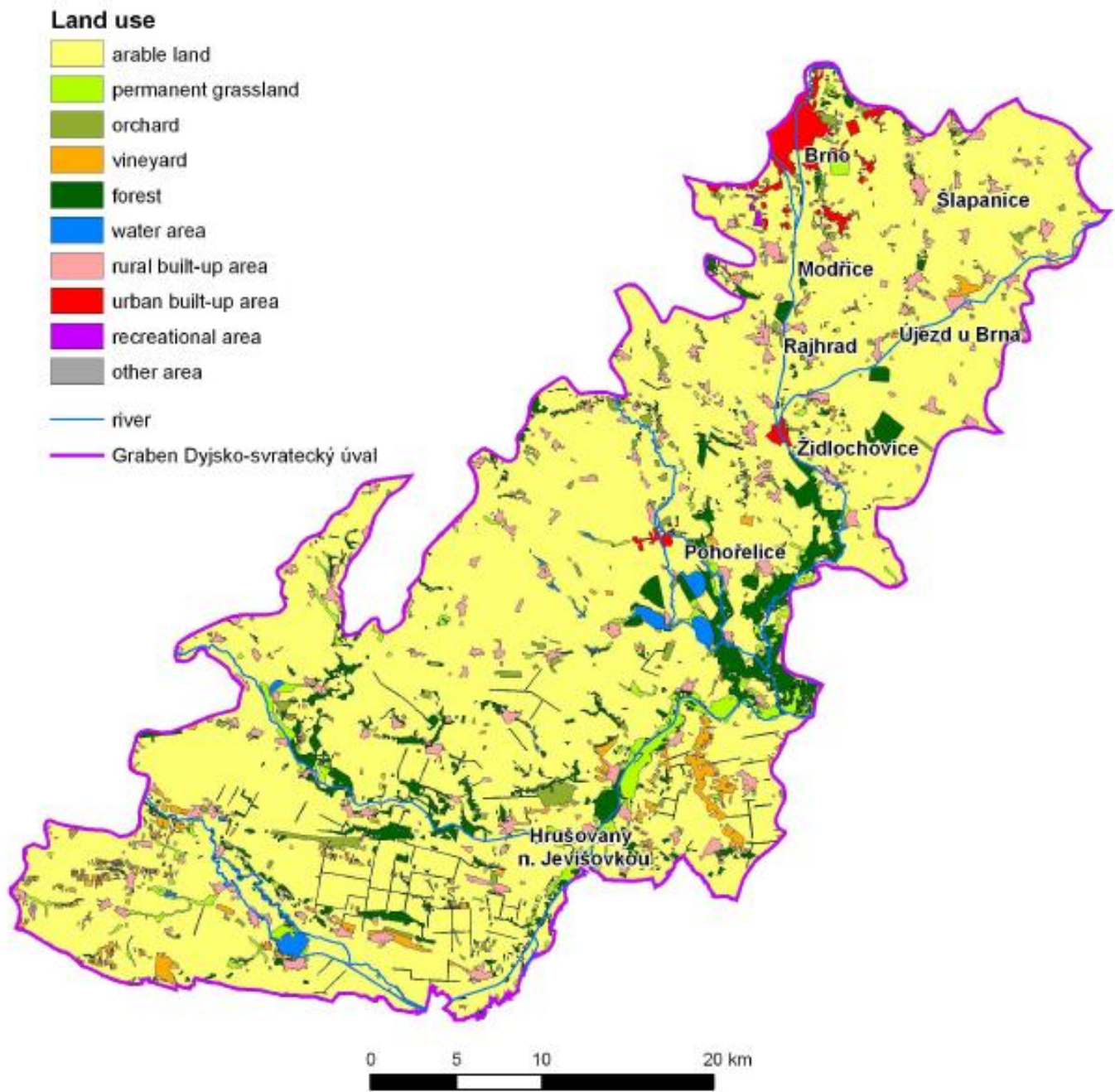

In the new colour edition of the Czechoslovak military topographic maps S42 of 1990 1992 the impact of the 2 nd agrarian reforms and the later collectivization of Czechoslovak agriculture is clearly documented in the landscape (Fig. 7). The most common form of collectivization was the agricultural cooperative (in Czech Jednotné zemědělské družstvo,JZD). Collectivization was implemented in three stages (1949-1952, 1953-1955, and 1955-1960). Every piece of land was cultivated regardless of the expense involved, and the soil became heavily polluted with chemicals. The share of arable land reached its maximum of $82.05 \%$ around $1953-1955$, while the area of permanent grassland decreased 
to $2.82 \%$ (Table 1). The goal of collectivization was to encourage large-scale farming that could také advantage of modern technologies and powerful farm equipment. The private field boundaries, therefore, were plough up, to create larger land units. Large tracts of fields replaced the former patchwork of small farm parcels in the Dyjsko-svratecký úval Graben. During the collectivization, a lot of scattered vegetation was destroyed. Large collectivized tracts still prevail in rural landscape of the Graben. Agrochemical inputs for crop growing, however decreased substantially after 1990.

A system of windbreak hedges was planted in the warm a dry hilly lands Jaroslavická pahorkatina and Drnholecká pahorkatina following World War II to protect against accelerated wind soil erosion (Fig. 6). These windbreaks hedges now serve as biocorridors in the managed agriculture ecosystems that makes up the present monotonous rural landscape. These strips of trees and brushes also serve as refuges and shelter for animals in the barren rural landscapes of these hilly lands. Around 20 hectares of windbreaks can be found, for example, in the warm and dry hills near the villages Čejkovice, Hevlín, Hodonice, Micmanice, Oleksovice and Velký Karlov.

A network of 3 water reservoirs, named Nové Mlýny, was constructed at the confluence of the Dyje R. and the Svratka R., the upper and central reservoir of the cascade being bulit between the years 1975 and 1982 (Fig. 7). The upper reservoir is used for recreation, while the central reservoir serves as a zone of tranquillity with an adjoining nature reserve. The Nové Mlýny reservoirs comprise the largest hydraulic engineering structure in the Moravia. Their construction also constitutes the most controversial Human intervention into nature in the area under study. The positive feature is the increase of water surface in the Graben to $1.96 \%$ by 1991 . During the central reservoir's construction, however, the village Mušov was demolished and today only the village church has been preserved on an island in the lake.

The renewed Czechoslovak colour military topographic maps S42 from 1990- 1992 document a considerable grow in Brno's urban landscape and the development of suburbanization in its surroundings.

Further municipalities out side the city hinterland were amalgamated with Brno in 1957, 1960, 1970 and 1980. The fragmented mosaic character of the Brno suburban landscape increased over this period. At the same time, there was a decrease in connectivity between ecologically more stable landscape segments and structures. Some suburban villages, such as Šlapanice in 1965, Modřice in 1994 and Rajhrad in 2000, were bestowed town privileges and became satellite towns, going on to develop their own urbanized landscapes. New suburban estates emerged in the northern part of the Graben near the satellite town of Modřice (Př́ižrenice, Heršpice, and Rebešovice). The share of built-up land in villages was also growing. Urbanization and industrialization had slowly but steadily reduced the amount of arable land from $82.05 \%$ in 1955 to $77.1 \%$ in 1992 . The share of built-up land increased to $8.19 \%$ in the year 1992 . The sprawl of built-up areas into the floodplains was an unfavourable effect of this growth.

The S42 maps show the D1 and D2 motorways (constructed between 1969 - 1980) in the northern and eastern part of the Graben, a typical transportation landscape being formed where they cross (forming transportation node). The D2 motorway (Brno to Bratislava, Slovakia) causes a great deal of fragmentation in the Graben's landscape.

During the second half of the 20th Century, all of the main rivers in the Graben Dyjskosvratecký úval were trained. The Czechoslovak military map S52 of 1954 show the regulation of the Svratka R. near the village Uherčice (Fig. 6). The length of the Svratka 
riverbed was shortened to $35.33 \mathrm{~km}$ (Table 2) and the sinuosity index decreased to 1.22 (Table 3). In the 1991, the length of the Jihlava riverbed was slightly shortened to $24.52 \mathrm{~km}$ and the sinuosity index slightly decreased to 1.36 . River training completed the process of floodplain fragmentation, resulting in very limited natural geomorphical processes. Grasslands had nearly disappeared from the river and valley floodplains. The construction of Nové Mlýny reservoirs on the Dyje R. in 1978 resulted in a substantial decline in the confluence area of the rivers Svratka and Jihlava. The lengths of the Dyje R. were shortened to $59.11 \mathrm{~km}$ (Table 2). The junction of the creek Skalička of the Yazoo type was changed and the confluence moved from the village of Božice upstream to the present day confluence near the village of Lechovice.

Fig. 7: Land-use in the Dyjsko-svratecký úval Graben around 1991-1992

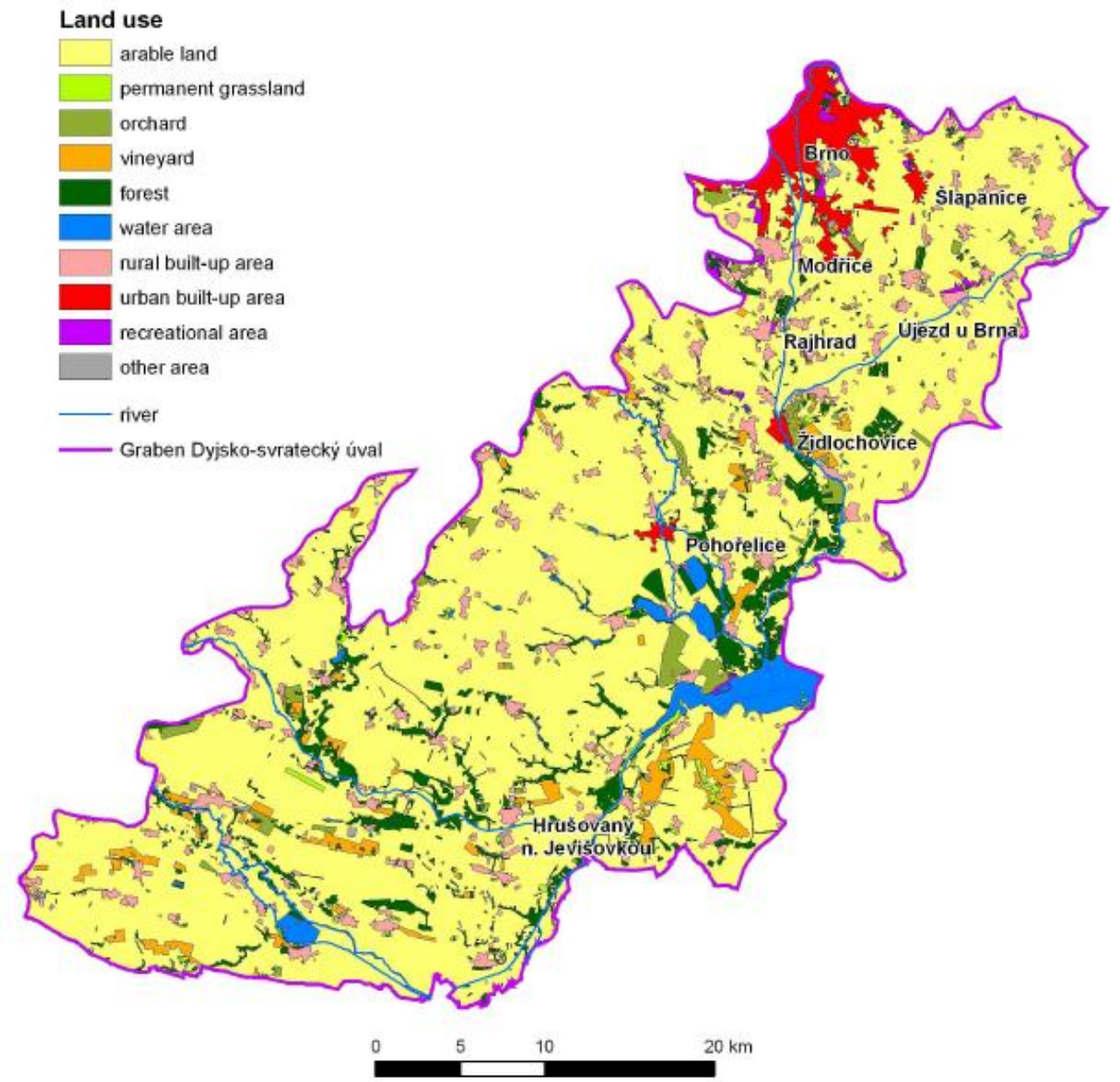

The area of arable land in the Graben had decreased to $77.1 \%$ by 1992 and the share of permanent grassland decreased to its historic minimum of $1.00 \%$ (Table 1). The share of forest remained stable at $6.34 \%$. Following a decrease in the area of vineyards in the pastwar period to $1.80 \%$, their share had increased to $2.76 \%$ by 1992 . 


\section{Landscape structures at the beginning of the 21st Century}

Contemporary landscape structures are shown on the digital raster Basic map of the Czech Republic in the scale 1:10 000 (Czech Office for Surveying, Mapping and Cadastre Prague) and on updated aerial and satellite images. The share of arable land decreased after 1989 to $75.86 \%$ (Table 1). The share of permanent grassland slightly increased to $1.55 \%$ and the share of forest increased to its historical maximum of $7.18 \%$. The share of recreational land remained stable at $0.39 \%$.

Digital maps show rapid grow of built-up land (urban and rural combined), which reached a historic maximum of $8.50 \%$ (Fig. 8).

Fig. 8: Land use in Dyjsko-svratecký úval Graben around 2002 - 2006

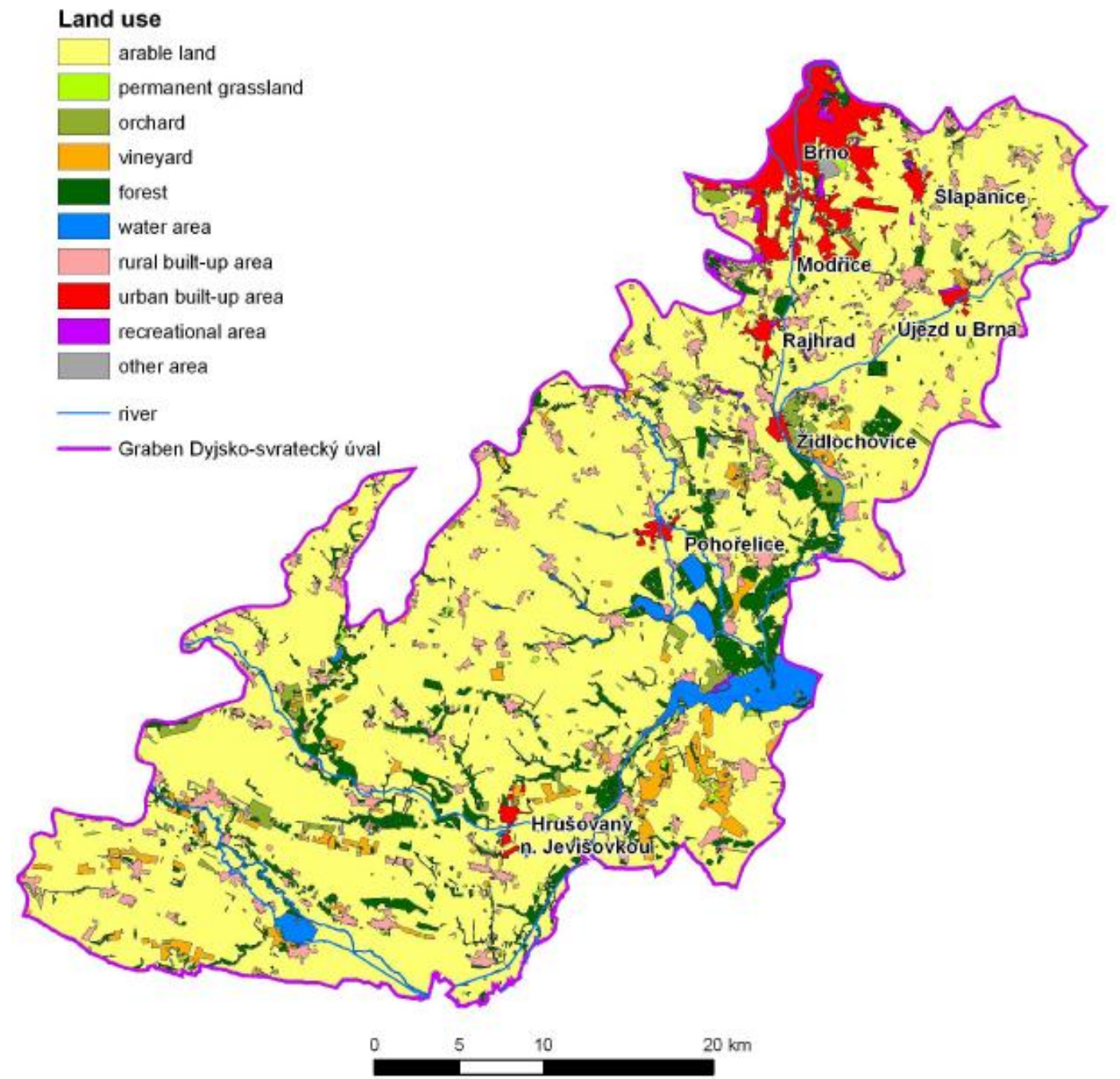


The part of City core of the Brno and its suburbs represent a very diversified built-up environment ranging from old factories in the Svitava R. industrial zone and remnants of old villages to new multi-storey building zones and the Brno - Tuřany airport.

For some parts of the Graben display typical mosaics of crops and viticulture plantations, providing the Graben landscape with a special landscape within the Czech Republic (e.g. Dunajovické vrchy Hilly land with their vineyards, grass the rows of vines and wooden poles). To the south from the City of Brno large business complexes has been developer (e.g. the Olympia complex near the town of Modřice) and industrial areas where the uppersoil-profile is no longer exposed and large plots are paved or covered by asphalt (hardscape). Without a lack of bare soil nearby, a hardscape requires artificial methods of drainage/runoff in order to carry away the sometimes massive volume of runoff (e.g. thunderstorm or melting snow) that would normally be mostly absorbed into the ground to recharge groundwater.

\section{QUANTITATIVE ASSESSMENT OF CHANGES TO THE RIVER NETWORK}

Rivers in the Dyjsko-svratecky Graben are typical low-energy rivers that even in the 18 th Century freely meandered and anabranched in the floodplains. Floodplains acted as ecotons between the valley slopes and river channels. Vertical aggradation of the floodplains occurred during floods. Anthropogenic impact includes such features as the construction of fishponds, weirs and races (especially millraces). Typical floodplain ecosystems existed up until the middle of $19_{\text {th }}$ Century including floodplain forests, meadows and pastures. During the Little Ice Age, frequent flooding limited settlement in the floodplains. The ecosystems of the warm floodplain of the Dyje River, downstream of the town of Znojmo, differed from these in that where the maps of the 1 st Austrian Military Survey also show arable land. River training, which begun around 1850 resulted in the straightening and incision of riverbeds, the construction of embankments, shortening of river courses and a general fragmentation of the floodplains. In this way, the floodplains gradually lost their function as ecotones. Many of the rivers were shortened and their sinuosity reduced (see Tables 2 and 3). After 1945, the maps show urbanization of the floodplains and construction of Nové Mlýny water reservoirs. At the same time, however, were being revitalized, including large fishpond system near the town of Pohořelice on the Jihlava R. The most channelized river beds, now technically represent hardscapes as they require a barrier to retain water, instead of letting it drain into the surrounding soil.

\section{CONTEMPORARY RELATIONSHIP BETWEEN RELIEF AND LAND-USE PATTERNS}

Lowland plains and arable land are the typical land-use patterns of the Graben Dyjskosvratecký úval (Fig. 9). Urban built-up areas represented by the City of Brno and its satellite towns of Modřice, Rajhrad and Šlapanice have only really developed in the northernmost part of the Graben. In the floodplain Svitavsko-svratecká niva remnants of floodplain forests are still preserved. Fields and water reservoirs are typical for the Středodyjská niva floodplain, while large fields are typical features characterizing the lowland plains that are made up of Quaternary and Neogene deposits. Small patches of forests are found only on steeper slopes of hills (e.g. left steep slope of the Jevišovka R. valley). The terraced slopes of some of undulating plains are covered by vineyards ((e.g. ridges of the Dunajovické vrchy Hills and of the Jaroslavická pahorkatina Hilly land). Viticulture and fruit orchards are also typical of such hilly lands. Výhon, the highest hill in the Graben, is a typical example of this type of contemporary land-use pattern. 


\section{Fig. 9: The present day relationship between landform and land use pattern}
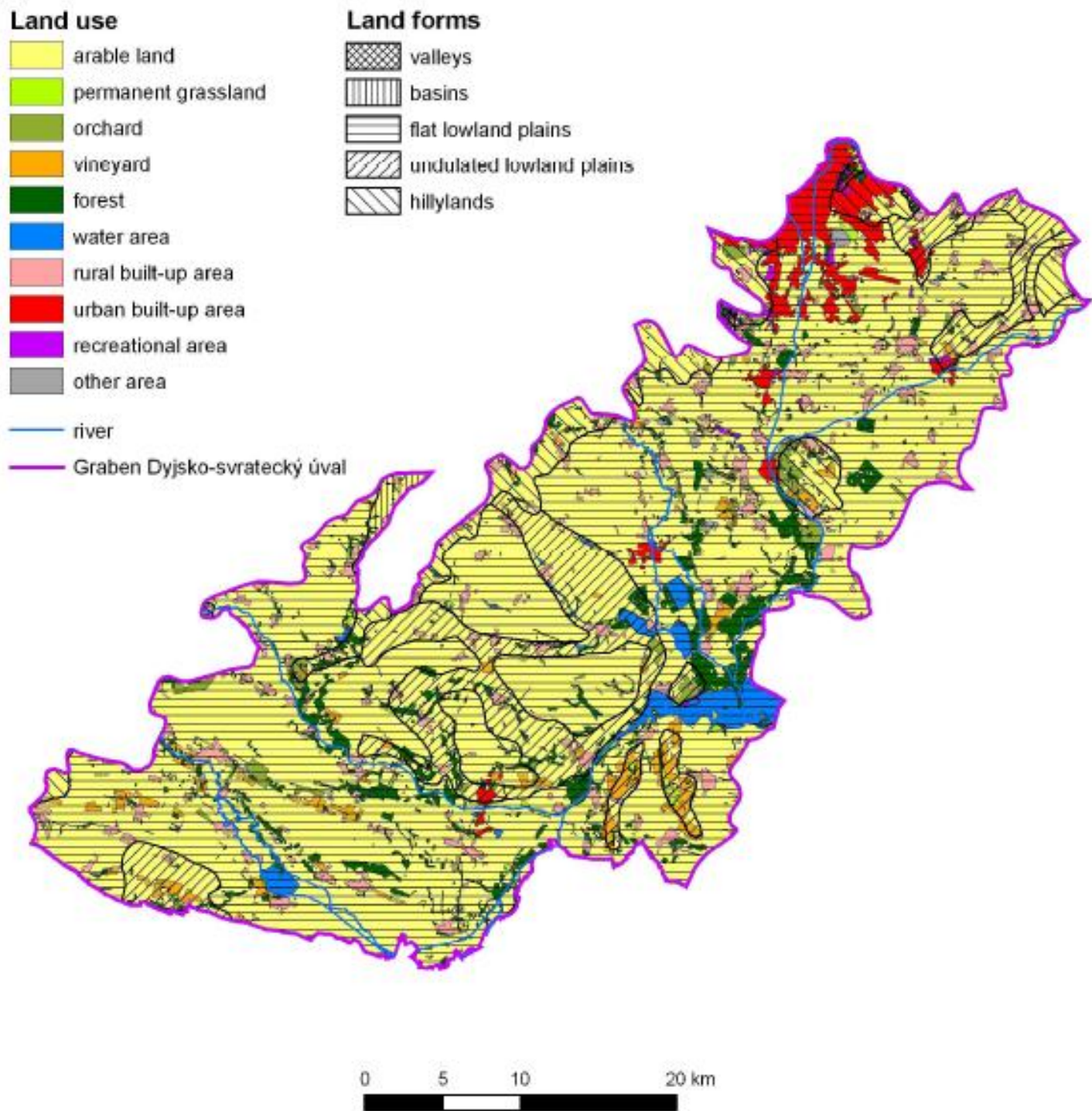

\section{QUANTITATIVE ASSESSMENT OF LANDSCAPE PATTERN DEVELOPMENT}

The digital processing of historical maps enables us to make a quantitative assessment of landscape pattern changes over the period between 1840 and 2006 (see Table 1). By overlying the vectored maps it was also possible to quantitatively assess the number of land-use changes over time and degree of stability in landscape pattern over the research period (see Fig. 10 and 11). For example, Table 5 illustrates the type and percentage change in landscape us over the study period, while Table 6 provides data on the type and percentage of stable plots. Table 7 and 8 respectively show the dynamics of land-use change between individual periods and the types of land-use changes in individual periods. The northern part of the Dyjsko-svratecký úval Graben lies adjacent to the residential and 
industrial Brno agglomeration and therefore is exposed to heavy anthropogenic impact. Rural landscapes prevail in the southern

Fig. 10: Number of changes in land-use in the landscape of the Dyjsko-svratecký úval

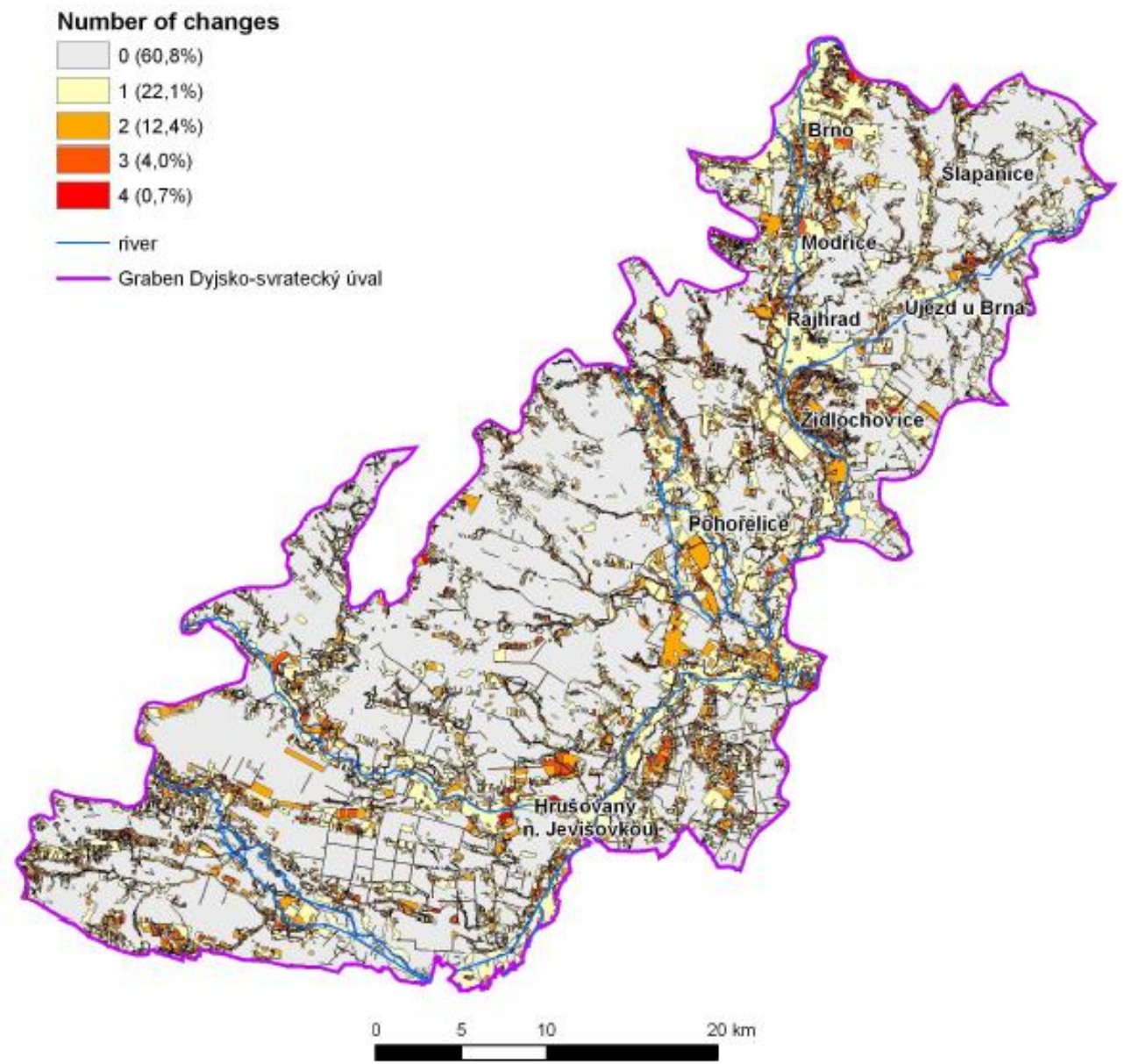

Part of the Graben, even though, even due to the effect of such changes such as farm mechanization and urban development of villages, the distinction between rural and urban landscapes is much less clear-cut today.

Around $61 \%$ of the Graben is represented by stable plots, where land-use has remained stable over the last 170 years (Fig. 11, Table 6, Table 4). These are mostly rural landscapes where agricultural land - use has not changed significantly during that time. Nevertheless, even the rural countryside is not completely static entity as it represents the product of continuous interaction between humans and the land. One change of land use occurred on $22 \%$ of plots, 2 changes on $12 \%$ of plots and 3 changes on $4 \%$ of plots. Large-scale change, represented by 4 changes, occurred on just $0.7 \%$ of plots. Floodplains are very dynamic structures with several changes in land-use occurring over the research period of time (Fig. 
10). Fishponds, which were mostly situated in floodplains, decreased in number between the $1_{\text {st }}$ and 2 nd Austrian Military Surveys, being inverted to arable land after draining. Over the period from 1836 to 2006 about $79 \%$ of the patches of floodplain Jihlavsko-svratecká niva changed their use as meandering and anastomosing river courses were trained, straightened and embanked. The most intensive changes took place over the period 1836 1876 with the ploughing of meadows $(22.19 \%)$, felling of floodplain forests and their change into arable land. Built-up areas expanded into the floodplains over the period 1991 2006. Protected areas now represent "islands" surrounded by a "sea" of sprawling lowdensity development.

Table 4: Changes in land-use as a percentage of totals territory in the Dyjskosvratecký úval Graben over period 1836 - 2006

\begin{tabular}{|l|l|}
\hline NUMBER OF CHANGES 1836-2006 & \% OF TERRITORY \\
\hline 0 & 60.98 \\
\hline 1 & 22.30 \\
\hline 2 & 12.13 \\
\hline 3 & 3.89 \\
\hline 4 & 0.70 \\
\hline
\end{tabular}

Table 5: Type of land-use changes

\begin{tabular}{|l|l|l|}
\hline TYPE OF CHANGE & $\begin{array}{l}\text { PERIOD OF } \\
\text { CHANGE }\end{array}$ & OF TERRITORY \\
\hline $\begin{array}{l}\text { PERMANENT GRASSLAND INTO ARABLE } \\
\text { LAND }\end{array}$ & 21111 & 4.67 \\
\hline $\begin{array}{l}\text { PERMANENT GRASSLAND INTO ARABLE } \\
\text { LAND }\end{array}$ & 22111 & 2.05 \\
\hline ARABLE LAND INTO BUILT-UP LAND & 11777 & 1.28 \\
\hline ARABLE LAND INTO BUIIT-UP LAND & 11177 & 2.09 \\
\hline VINEYARDS INTO ARABLE LAND & 41111 & 1.17 \\
\hline FORESTS INTO ARABLE LAND & 51111 & 0.97 \\
\hline
\end{tabular}

Period of change: First numeral: land use 1836-1841, second numeral: 1875-1876, third numeral: 1953-1955, fourth numeral: 1991- 1992, fifth numeral: 2002-2006. Codes: 1. Arable land, 2. Permanent grassland, 3. Orchard and garden, 4. Vineyard, 5. Forest, 6. Water area, 7. Rural built-up area, 8. Urban built-up area, 9. Recreational area 0. Others 
Table 6: Areas and percentage of stable plots in the Dyjsko-svratecký úval over the period 1836-2006 Stable plots

\begin{tabular}{|l|l|l|l|}
\hline INDEX & TYPE OF LAND USE & AREA IN HECTARES & $\%$ \\
\hline 1 & ARABLE LAND & 83652. & 57,0 \\
\hline 2 & PERMANENT GRASSLAND & 176.77 & 0.1 \\
\hline 3 & ORCHARD & 6.73 & 0.01 \\
\hline 4 & VINEYARD & 331.81 & 0.2 \\
\hline 5 & FOREST & 2276.40 & 1.6 \\
\hline 6 & WATER SURFACES & 2.70 & 0.01 \\
\hline 7 & BUIT-UP LAND & 2261.35 & 1.5 \\
\hline
\end{tabular}

Table 8: Type of changes in land use in individual periods during 1841 - 2006

\begin{tabular}{|c|c|}
\hline PERIOD & TYPE OF CHANGE OF LAND USE IN \% \\
\hline $1841-1876$ & \begin{tabular}{ll|}
21 & 7.42 \\
12 & 1.72 \\
41 & 1.99 \\
51 & 1.52 \\
14 & 1.25
\end{tabular} \\
\hline $1876-1955$ & $\begin{array}{|ll|}21 & 4.39 \\
17 & 2.14 \\
15 & 2.12 \\
41 & 2.08 \\
13 & 1.25 \\
51 & 1.05 \\
\end{array}$ \\
\hline $1955-1992$ & \begin{tabular}{|ll}
17 & 3.42 \\
14 & 1.84 \\
13 & 1.60 \\
21 & 1.50 \\
15 & 1.38 \\
5.1 & 1.03 \\
\end{tabular} \\
\hline $1992-2006$ & $\begin{array}{|ll|}15 & 1.16 \\
17 & 0.92 \\
12 & 0.63 \\
31 & 0.61 \\
\end{array}$ \\
\hline
\end{tabular}

Explanation: 1 - arable land. 2 - Permanent grassland. 3 - Orchards. 4 - Vineyards. 5 Forests. 6 - Water surfaces. 7 - Built-up land. 


\section{Fig. 11: Stable plots within the Dyjsko-svratecký úval}

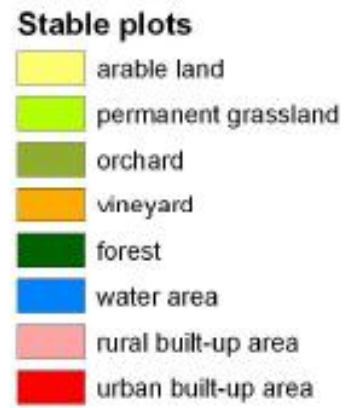

\section{Unstable plots}

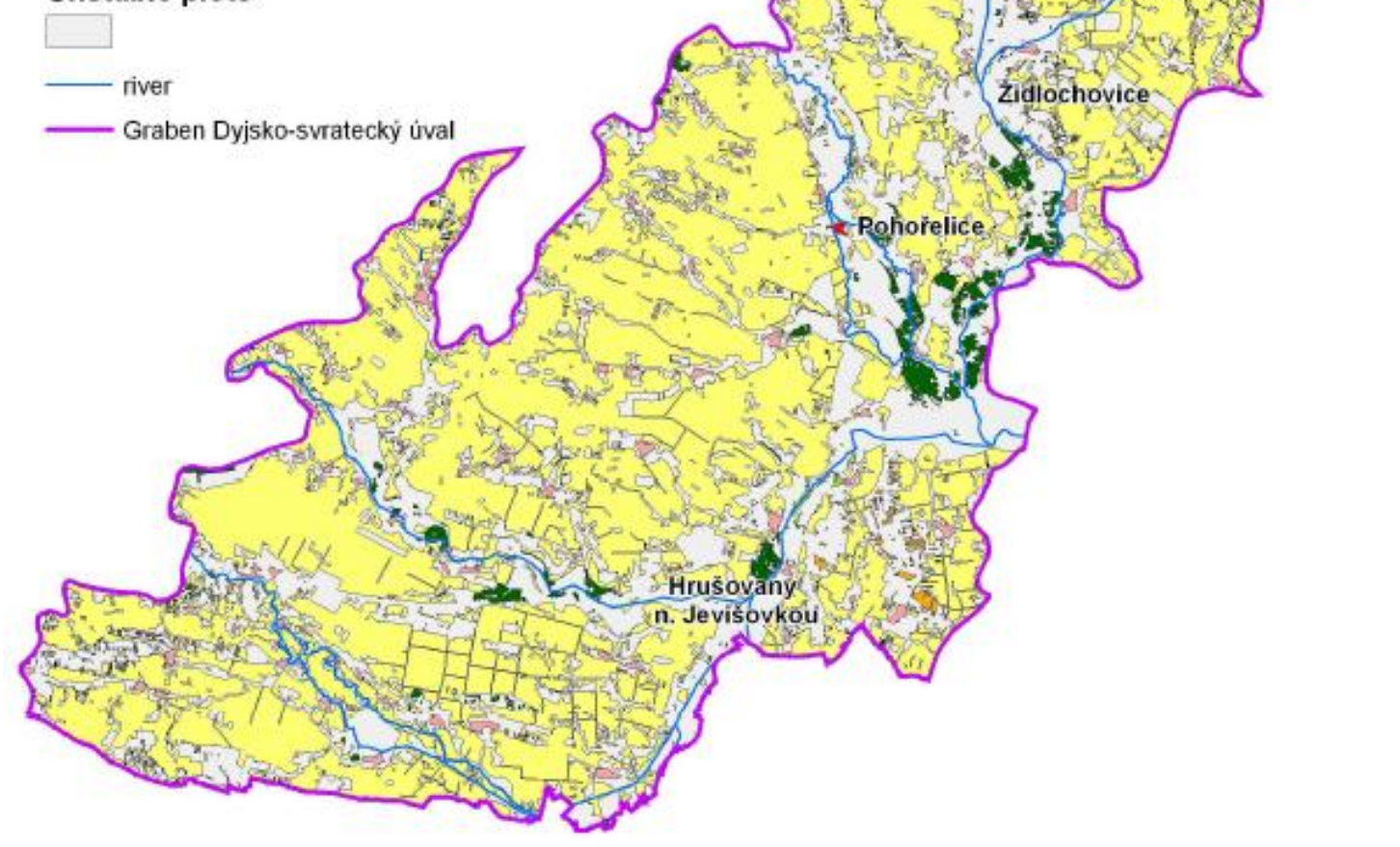

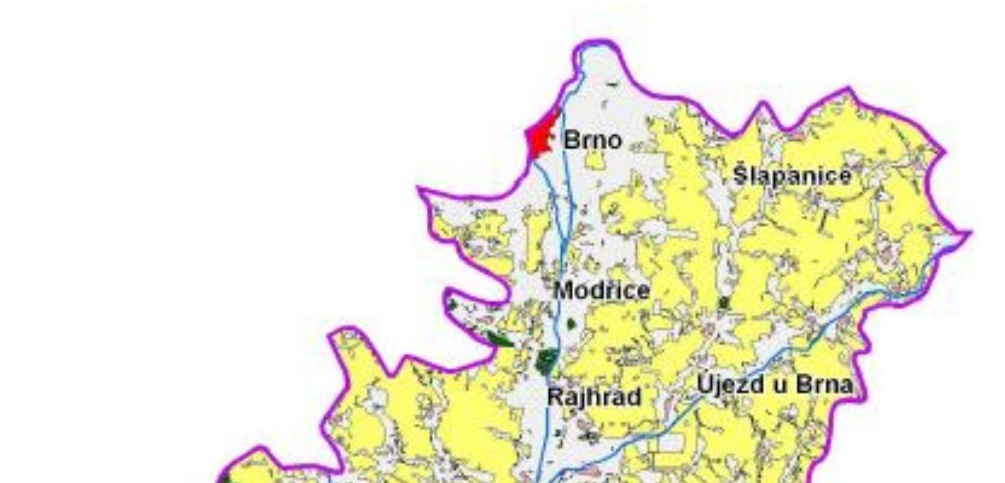

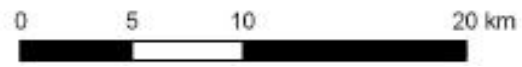

\section{DRIVING FORCES}

The period between 1764 -2006 includes the beginning and development of the modern Central-European cultural landscape. At the time of the $1_{\text {st }}$ Austrian Military Survey of 1764 - 1768, Europe's economy was overwhelmingly based on agriculture. Agriculture was the greatest user of land and played a key-role in the shaping the landscape over much of the Graben Dyjsko-svratecký úval. The land was largely owned largely by wealthy and frequently aristocratic landowners. From 1764 onwards, however, several important technological and socioeconomic changes began to have an impact on the rural landscapes (Kjeldsen-Kragh 2007). The most conspicuous change in the rural landscape of the Graben Dyjsko-svratecký úval was caused by Austrian agrarian reform (so called raabization) in 
the second half of the 18 th century, which resulted in part of each dominion's fields being divided amongst the peasants.

Over the period 1764 -1914 agriculture was an engine of economic growths and landscape change. The first stages of the technical-scientific revolution in the agriculture initiated both growth in production and changes to rural landscapes through technological advances within the agricultural sector (e.g. new systems of cropping using a three course of rotation, that included clover, the introduction of new field crops such as potato or maize, and invention of steel plough and the seed drill). Thus, an essentially organic form of agriculture was gradually replaced by a farming system that depended on energyintensive inputs and the intensive use of arable land. Smaller agricultural estates that did not use the fertilizer and mechanization could not longer survive.

The technical revolution around the time of the 2nd Austrian Military Survey of 18361841 caused a boom in industry and trade in the Brno, which resulting in the demolition of the medieval fortification between 1858 and 1863 and the rapid sprawl of an urbanized landscape (compare Figs. 4 and 5). The maps show, that the removal of the fortification belt facilitated the town spread in almost every direction.

Despite spectacular increases in productivity following World War I, agriculture has experienced a number of difficulties since 1914 and especially during the Great Depression of the 1930s.

Food production was the primary purpose of the agricultural landscapes in the Graben Dyjsko-svratecký úval, but in $20_{\text {th }}$ century, however, the concerns for other objectives, such as conservation, biodiversity, recreation, and scenery, have increased in importance. The tractor became the main source of mechanization in agriculture following World War II.

Collectivization also caused changes in the intravilane of rural settlements. Before collectivization, villages contained the farmer's houses with stables for horses, sheds for cows, henhouses, and so on.

Villages also had dung-holes, which often caused environmental pollution. Following collectivization, collective farms were built extravilane, often far from settlements.

Private field boundaries were plough up thus creating large land units. During the collectivization much scattered vegetation was destroyed. Large collectivized tracts of land are still a dominant feature of the rural landscape in the Graben today.

A grow of hardscape and the chaotic development of the suburban areas has been typical landscape process since 1989.

\section{CONCLUSION}

Detailed historical topographic maps comprise an important source of information for landscape-ecological studies into the development of cultural landscapes in the last 242 years. Digital processing of maps in GIS milieu enables a high-quality assessment of the changes that have occurred in the landscape. Rural landscapes prevail in the Dyjskosvratecký Graben. The quantitative assessment of land use in these rural landscapes based on historical topographic maps has shown that use of arable lands over the period 1836 2006 remained stable. Field patterns, however, changed substantially in the second half of the 20th Century due to collectivization of agriculture. More dynamic changes in landscape structures occurred in the floodplains due to training of rivers and construction of fishponds and water reservoirs. 


\section{ACKNOWLEDGEMENTS}

The study is an output of Research Project MSM 6293359101'Research of biodiversity resources and indicators in the cultural landscape in the context of its fragmentation dynamics" and was supported through Grant No. 205/06/1024 of the Grant Agency of the Czech Republic "Geomorphology of the valley of the middle course of the Svratka River quaternary development and environmental aspects".

\section{REFERENCES}

Allaby, M. (2004). A Dictionary of Ecology. Second Edition, Oxford University Press, Oxford, 233: pp 440.

Boltižiar, M. (2007). Štruktúra vysokohorskej krajiny Tatier. Univerzita Konštantína filozofa v Nitre, Nitra, pp 248.

Brázdil, R., Kirchner, K.. (2007). Selected Natural Extremes and their impacts in Moravia and Silesia. Masaryk university, Czech Hydrometeorological Institute, Institute of Geonics of the Czech Academy of Sciences, v.v.i. Brno-Praha-Ostrava, 175: pp 431.

Demek, J., Havlíček, M., Mackovčin, P. \& Stránská, T (2007). Brno and its surroundings: a landscape-ecological study. Ekologie krajiny (Journal of Landscape Ecology), Vol. 0 (0): $32-53$.

Dřímal, J., Peša, V. (1973). Dějiny města Brna 2, Blok, Brno, pp 378.

Jeleček, L. (1985). Zemédělství a pưdní fond v Čechách ve 2. polovině 19. století. Academia, Praha, pp 283.

Jeleček, L. (1991).Některé ekologické souvislosti vývoje zemědělské krajiny a zemědělství v Českých zemích. Český časopis historický 8 (:3): 375-394.

Jurnečková, R., Kolejka, J. (1999). Historický vývoj ekologické stability krajiny v nivě Svratky mezi Brnem a Novomlýnskými nádržemi. Sborník prací pedagogické fakulty Masarykovy univerzity 145, ř. Př́rodních věd č. 22, Geografie 11, Část A, $111-123$.

Kjeldsen-kragh, S. (2007). The Role of Agriculture in Economic Development. Copenhagen Business School Press, Copenhagen, pp 412.

Kratochvíl, A. (1910). Vlastivěda moravská II. Místopis Židlochovský okres. Musejní spolek v Brně, Brno, 7: pp 361.

Kratochvíl, A. (1913). Vlastivěda moravská, II. Místopis, Pohořelský okres. Musejní spolek v Brně, Brno, 157, 165, 193, 200: pp 256.

Lipský, Z. (1999). Sledování změn v kulturní krajině. Česká zemědělská univerzita v Praze, Praha, pp 71.

Lipsky, Z. (2007). Methods of monitoring and assessment of changes in land use and landscape structure. Czech Society for Landscape Ecology CZ- IALE, Brno, Ekologie krajiny (Journal of Landscape Ecology), Vol. 0 (0):105 - 118.

Ložek, V. (2003). Povodně a život nivy. Bohemia Centralis (Praha) 26: 9-24.

Mackovčin, P. (2007). Chráněná území ČR IX - Brněnsko. Agentura ochrany př́rody a krajiny ĆR a EkoCentrum Brno, Praha, pp 932.

Musil, J.F. (1987). Od stezek k dálnicím. NADAS, Praha, 210: pp 214.

Nekuda, V. (1997). Morava ve středověku. Moravské zemské museum, Brno.

Němec, J., Hladný, J. (2006). Water in the Czech Republic. Ministry of Agriculture of the 
Czech Republic, Praha, 68: pp 256.

Peřinka, F.V. (1904). Vlastivěda moravská II Místopis. Znojemský okres. Musejní spolek, Brno, pp 551.

Peřinka, F.V. (1905). Vlastivěda moravská II Mistopis. Brněnský okres. Musejní spolek, Brno, 94: pp 392.

Pyšek, P., Sádlo, J. \& Mandák, B. (2002). Catalogue of alien plants of the Czech Republic. Preslia, 74: 97-186.

Pucharová, Z. (2007). Druhotná krajinná štruktúra. Univerzita Konštantína Filozofa v Nitre, Nitra, pp 124.

Skokanová, H., Havlíček, M. \& Svoboda, J. (2008). Průběžné výsledky výzkumného záměru MSM 629333359101, části kvantitativní analýza dynamiky vývoje krajiny ČR. In: Pešková, K. (Ed.): Sborník symposia GIS Ostrava 2008, TANGER spol. s.r.o. (CD)

Slavík, F.A. (1897). Vlastivěda moravská II Místopis. Jaroslavský okres. Musejní spolek, Brno, (38) pp 141.

Vlček, Vl. (1984). Zeměpisný lexikon ČSR Vodní toky a nádrže. Academia, Praha, pp 315. 